\title{
Building the Holocene clinothem in the Gulf of Papua: An ocean circulation study
}

Rudy Slingerland

The Pennsylvania State University

Robert W. Selover

The Pennsylvania State University

Andrea S. Ogston

University of Washington

Timothy R. Keen

Naval Research Laboratory, Stennis Space Center

Neal W. Driscoll

Scripps Institution of Oceanography

See next page for additional authors

Follow this and additional works at: https://scholarworks.wm.edu/vimsarticles

Part of the Marine Biology Commons

\section{Recommended Citation}

Slingerland, Rudy; Selover, Robert W.; Ogston, Andrea S.; Keen, Timothy R.; Driscoll, Neal W.; and Milliman, John D., "Building the Holocene clinothem in the Gulf of Papua: An ocean circulation study" (2008). VIMS Articles. 271.

https://scholarworks.wm.edu/vimsarticles/271 


\section{Authors}

Rudy Slingerland, Robert W. Selover, Andrea S. Ogston, Timothy R. Keen, Neal W. Driscoll, and John D. Milliman 


\title{
Building the Holocene clinothem in the Gulf of Papua: An ocean circulation study
}

\author{
Rudy Slingerland, ${ }^{1}$ Robert W. Selover, ${ }^{1}$ Andrea S. Ogston, ${ }^{2}$ Timothy R. Keen, ${ }^{3}$ \\ Neal W. Driscoll, ${ }^{4}$ and John D. Milliman ${ }^{5}$ \\ Received 31 August 2006; revised 21 August 2007; accepted 15 November 2007; published 28 March 2008.
}

[1] This paper investigates the role that tidal and wind-driven flows and buoyant river plumes play in the development of the Holocene clinothem in the Gulf of Papua. Time series data from bottom tripods and a mooring were obtained at four locations near the mouth of the Fly River during portions of 2003 and 2004. Flows in the Gulf of Papua during calendar year 2003 were hindcast every $3 \mathrm{~h}$ using the Navy Coastal Ocean Model (NCOM) with boundary conditions from the Navy Atmospheric Prediction System, the east Asian seas implementation of NCOM, and the OTIS Tidal Inversion System. Results show that tidal flows on the modern clinoform are strong and are landward and seaward directed. Peak spring tidal velocities can provide the shear stresses necessary to keep sediment up to sand size in motion as the wind-driven and baroclinic currents distribute it from the river mouths across and along the shelf in two circulation states. During the monsoon season, the clinoform topset is swept by a seaward surface flow and landward bottom flow, reflecting river plumes and coastal upwelling. Seaward, this structure evolves into a SW directed surface current over the clinothem foreset with accompanying landward directed near-bed currents that trend obliquely up the foreset to the WSW over much of the clinothem. During the trade wind season, the inner and outer topset are swept by NE directed, contour-parallel surface currents, underneath which lie obliquely landward near-bed currents. These modeled flows and complex gyres in shallow water coupled with wave- and current-supported gravity flows or river floods can explain the form, internal clinoform shapes, and mineralogy of the modern Gulf of Papua clinothem.

Citation: Slingerland, R., R. W. Selover, A. S. Ogston, T. R. Keen, N. W. Driscoll, and J. D. Milliman (2008), Building the Holocene clinothem in the Gulf of Papua: An ocean circulation study, J. Geophys. Res., 113, F01S14, doi:10.1029/2006JF000680.

\section{Introduction}

[2] Clinothems are heterolithic, coarsening upward sedimentary sequences (as per Mitchum et al. [1977]) through which chronostratigraphic horizons, called clinoforms, cut obliquely. They are the basic building blocks of modern and ancient continental shelves. If we knew the functional relationship between their sedimentary characteristics and the processes that create them, we could predict better the long-term fate of shelf sediment and hindcast the history of relative sea level, sediment flux, and shelf processes as recorded by their clinoforms.

\footnotetext{
${ }^{1}$ Department of Geosciences, Pennsylvania State University, University Park, Pennsylvania, USA.

${ }^{2}$ School of Oceanography, University of Washington, Seattle, Washington, USA.

${ }^{3}$ Naval Research Laboratory, Stennis Space Center, Mississippi, USA.

${ }^{4}$ Scripps Institution of Oceanography, La Jolla, California, USA.

${ }^{5}$ School of Marine Science, College of William and Mary, Gloucester Point, Virginia, USA.

Copyright 2008 by the American Geophysical Union. 0148-0227/08/2006JF000680
}

[3] Clinothems have long been treated as two-dimensional sedimentary bodies built by relatively uniform seaward progradation of a shore face, delta, or a subaqueous clinoform. Consequently, most contemporary depositional models focus on offshore, downslope transport mechanisms, even though Driscoll and Karner [1999] noted that many modern clinothems are built by oblique, along-shelf transport. Recent studies seem to confirm Driscoll and Karner's assertion. Late Holocene clinothems of the Mediterranean for instance, extend downdrift for hundreds of kilometers from their parent deltas [Cattaneo et al., 2003, 2004] as do clinothems of both the Holocene Yellow and Yangtze Rivers [Chen et al., 2003; Hori et al., 2002; Liu et al., 2004, 2005] and the Amazon River [Nittrouer et al., 1986]. It seems clear that along-shelf sediment transport by winddriven, tidal, and thermohaline coastal currents with bottom Ekman transport must play a large role in the growth of these clinothems.

[4] As a companion paper indicates [Slingerland et al., 2008], the Holocene clinothem of the Gulf of Papua (GOP) (Figure 1) also has grown via along-shelf oblique transport. Its modern clinoform consists of a low-relief, shallow gradient, topset surface (upper shelf) extending up to $60 \mathrm{~km}$ seaward 


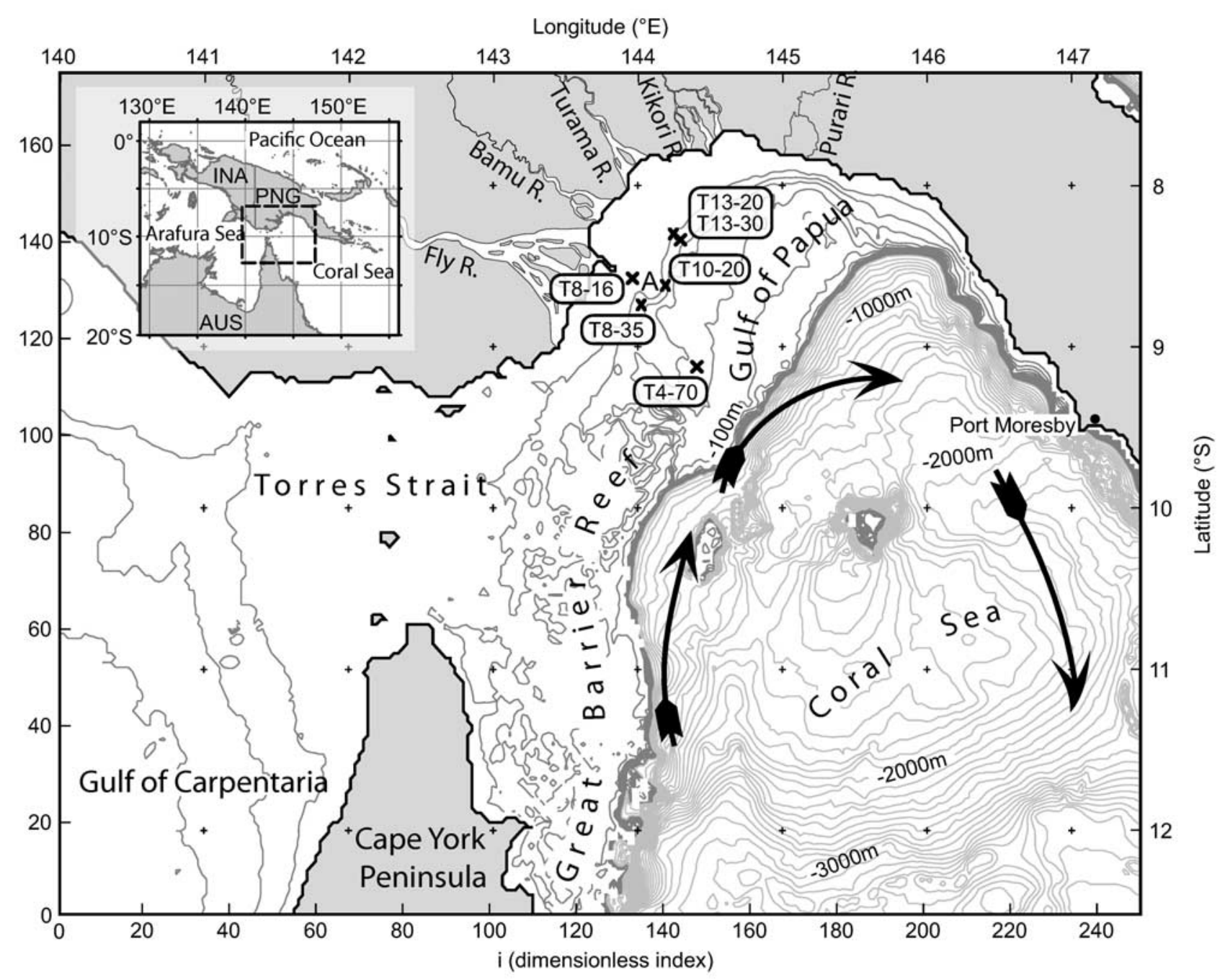

Figure 1. Study area showing location of Gulf of Papua and domain of this study. Site locations of instrument deployments are denoted by crosses. NCOM computational domain indices are given on left and bottom axes. Upper $300 \mathrm{~m}$ of bathymetry is contoured every $20 \mathrm{~m}$ (dark gray). Below $300 \mathrm{~m}$, contour interval is $100 \mathrm{~m}$ (light gray). Letter A indicates promontory in Holocene clinothem. Black arrows show general path of the Coral Sea Current. Inset shows location (dashed box) of PNG, Papua New Guinea; AUS, Australia; and INA, Indonesia.

from the shoreline, separated from the smoothly undulating foreset by a "rollover line" that lies in 20 to $30 \mathrm{~m}$ of water. The foreset surface extends down to $60 \mathrm{~m}$ at a mean gradient of $0.14^{\circ}$ [Harris et al., 1996; Slingerland et al., 2008; Walsh et al., 2004]. At its base, the foreset downlaps onto a drowned erosional landscape that forms a corrugated lower shelf extending a maximum of $100 \mathrm{~km}$ to the shelf edge.

[5] Downlapping relationships along the clinothem indicate that it consists of an older central lobe sandwiched between younger lobes to the north and south [Johnstone et al., 2006]. Thus the locus of sedimentation along this relatively continuous clinoform has shifted along strike over the Holocene. Furthermore, the central lobe consists of three major stratigraphic units that are separated by two surfaces of erosion or bypass and correlative surfaces defined by onor off-lap of strata [Slingerland et al., 2008]. The youngest unit, which dates at approximately 1600 radiocarbon years, consists of a facies that is acoustically more transparent and forms an on- and down-lapping wedge. These observations suggest that the youngest unit nucleated on a clinoform foreset and then expanded with time updip and downdip as well as laterally. Variable dip directions of internal clinoforms, an increased thickness on promontories of the foreset, and a preferential deposition of high-amplitude reflectors in swales [Slingerland et al., 2008] all require a sediment transport process that is multidirectional and includes a significant component of sedimentation from suspension.

[6] The mineralogy of surficial sediments of the topset also provides an indication of sediment transport directions. Sediments delivered to the coast by the Fly River are subarkosic sands (62-90 $\mu$ fraction) and illite-dominated clays [Salomons and Eagle, 1990], whereas sediment from the steeper, northeastern rivers derived from a volcanogenic terrain are immature arkosic sands and smectite-dominated clays [Milliman et al., 2006; Slingerland et al., 2008]. The smectite-rich, arkosic sediments of the northeastern rivers are observed as far southwest as T13-20 in Figure 1, indicating that there must be a component of southerly 
transport along much of the topset with a convergence zone just north of the Fly River. There also must be millennialscale periods of erosion or bypass when the reflector surfaces are formed.

[7] This study tests the idea that the GOP clinothem is being built by, and these stratigraphic and sedimentologic observations therefore arise from, a combination of tidal and wind-driven flows (i.e., those suggested by Pratson et al. [2004] and Harris et al. [1993]) and sediment-laden positive buoyancy river plumes [Kineke et al., 1996; Kuehl et al., 1982; Nittrouer et al., 1996; Pratson et al., 2004]. Observations include time series of flow velocities throughout the water column, and instantaneous water surface elevations collected during 2003 and 2004 at four locations near the mouth of the Fly River in $20 \mathrm{~m}$ and greater water depths. These are combined with hindcasts from the U. S. Navy Coastal Ocean Model (NCOM) for calendar year 2003 to characterize the flow fields and infer sediment transport in the Gulf of Papua. Other sediment transport processes such as hyperpyncnal river plumes [Kostic and Parker, 2003a, 2003b], wave- and current-supported gravity flows [Friedrichs and Wright, 1994; Traykovski et al., 2000], and weak depositional sheet turbidity currents [Parker, 2006] may also cause subaqueous clinothems to form and grow; however, they are not directly modeled here and their relative importance in forming the GOP Holocene clinothem is the topic of other papers [Harris et al., 1993, 2004; Martin et al., 2008; Ogston et al., 2008; Walsh et al., 2004].

\section{Study Area}

[8] The study area is located in the Gulf of Papua, a semicircular embayment off the Coral Sea (Figure 1). It is bordered to the north and west by the mangrove shoreline of Papua New Guinea and merges into the Coral Sea to the east, which reaches depths of $4,000 \mathrm{~m}$. To the south and southwest lie the northern termination of the Great Barrier Reef and the Torres Strait respectively, where water depths rarely exceed $10 \mathrm{~m}$. At depths greater than about $60 \mathrm{~m}$, the northern gulf is floored by mixed siliciclastics and carbonates; at shallower depths, sediments are siliciclastic. Topsets of an older clinothem form the outer shelf [Slingerland et al., 2008], which is being downlapped by the clinoform of the modern clinothem.

[9] The gulf receives freshwater and sediment from five principal rivers: the Fly, Bamu, Turama, Kikori, and Purari, along with several smaller rivers. Their estimated collective freshwater discharge is about $15,000 \mathrm{~m}^{3} \mathrm{~s}^{-1}$ [Salomons and Eagle, 1990; Wolanski et al., 1984] Discharge is spread evenly among the seasons with small interannual changes such that the 100-year floods of the Fly and Purari are only about twice the size of the 2-year floods [Pickup, 1984]. Collectively these rivers deliver upward of $\sim 365 \mathrm{Mt} \mathrm{a}^{-1}$ of sediment to their respective floodplains and deltas, and the gulf [Milliman, 1995]. Although the Fly River transmits by far the largest water discharge $\left(7,000 \mathrm{~m}^{3} \mathrm{~s}^{-1}\right)$, its sediment load does not scale in proportion, the northern and eastern rivers having higher sediment yields by virtue of their more highly erodible sedimentary rocks [Brunskill, 2004] and narrow coastal plains [Brunskill, 2004; Milliman, 1995].

[10] Sediment delivered to the GOP shelf is thought to be distributed by a combination of tidal, wind-driven, and baroclinic currents [Harris, 1990; Harris et al., 1996, 2003; Keen et al., 2006; Milliman et al., 2004; Muhammad et al., 2004; Ogston et al., 2008; Slingerland et al., 2004; Walsh et al., 2004; Wolanski and Alongi, 1995; Wolanski et al., 1995b], but their relative contributions remain an open question. Walsh et al. [2004] suggest that fluid muds may also play an important role during the transition from monsoon to trade wind conditions, and recent observations have shown fluid-mud formation during energetic spring tide and trade wind conditions [Martin et al., 2008]. The low ${ }^{210} \mathrm{~Pb}$ activities and increased clay content of discrete decimeter-thick layers accumulating on the foreset of the clinothem [Crockett et al., 2008] are consistent with either fluid mud layers flowing from the topset or wave-generated varves (sense of Harris et al. [1993]).

[11] Tides on the shelf are mostly semidiurnal [Harris et al., 2004; Ogston et al., 2008; Wolanski et al., 1995b] and tidal ellipses are generally oriented perpendicular to the shoreline. Most of the shelf has a maximum spring tidal range of $4-5 \mathrm{~m}$. Tidal effects are generally uniform across the upper shelf, with increased amplitudes in the northwestern gulf as well as in areas of shallow bathymetry.

[12] Wind-driven currents show two dominant circulation states that are highly influenced by seasonal monsoon and trade winds [Gentilli, 1971; Hemer et al., 2004; Keen et al., 2006; Selover et al., 2006; Wolanski et al., 1995b] (Figure 2). Winds during the Austral monsoon season from December to March are generally weak $\left(1-2 \mathrm{~m} \mathrm{~s}^{-1}\right)$ and from the northwest, but periods of rapid intensification or breakouts occur also during this season. By April (day 90 in Figure 2) the trade winds have commenced. These winds are strong $\left(4-5 \mathrm{~m} \mathrm{~s}^{-1}\right)$, sustained, and from the southeast (SE), with a large fetch over the GOP. In November the trade winds weaken, and December marks a transition period of weak variable winds heralding the return of the monsoons. Few documented cyclones have passed over the GOP [Lourensz, 1981], suggesting that storm sedimentation is not an important process.

[13] The South Equatorial Current (SEC), a large, westward geostrophic flow, is also important in driving circulation over the Holocene clinothem in the GOP [Wolanski, 1994]. The SEC approaches Australia at $\sim 18^{\circ} \mathrm{S}$ and bifurcates when it reaches the Queensland Plateau, exiting as the East Australian Current (EAC) to the south $(\sim 6 \mathrm{~Sv})$, and the Coral Sea Current (CSC) to the north $(\sim 6 \mathrm{~Sv})$ [Bostock et al., 2006]. The CSC forms a clockwise gyre that sweeps along the outer shelf of the GOP from the south and follows the southeastern Papua New Guinea peninsula as it exits the gulf to the east [Andrews and Clegg, 1989]. From mid-2002 to mid-2003 the Southern Oscillation Index was persistently negative but of low magnitude, potentially resulting in a weakened CSC during the course of this study. But Ridgway et al. [1993] found no significant modification of the Hiri Current strength in the Coral Sea during the 1986-1987 El Nino-Southern Oscillation event in the Western Pacific. On the basis of this limited evidence we assume that our hindcasts are representative of typical CSC conditions.

[14] Earlier studies on the interaction between freshwater plumes and the Great Barrier Reef [Hemer et al., 2004; Keen et al., 2006; Wolanski and Alongi, 1995; Wolanski et al., 1995b] provide some interesting predictions of coastal flows and sediment transport in the GOP region. Wolanski et 


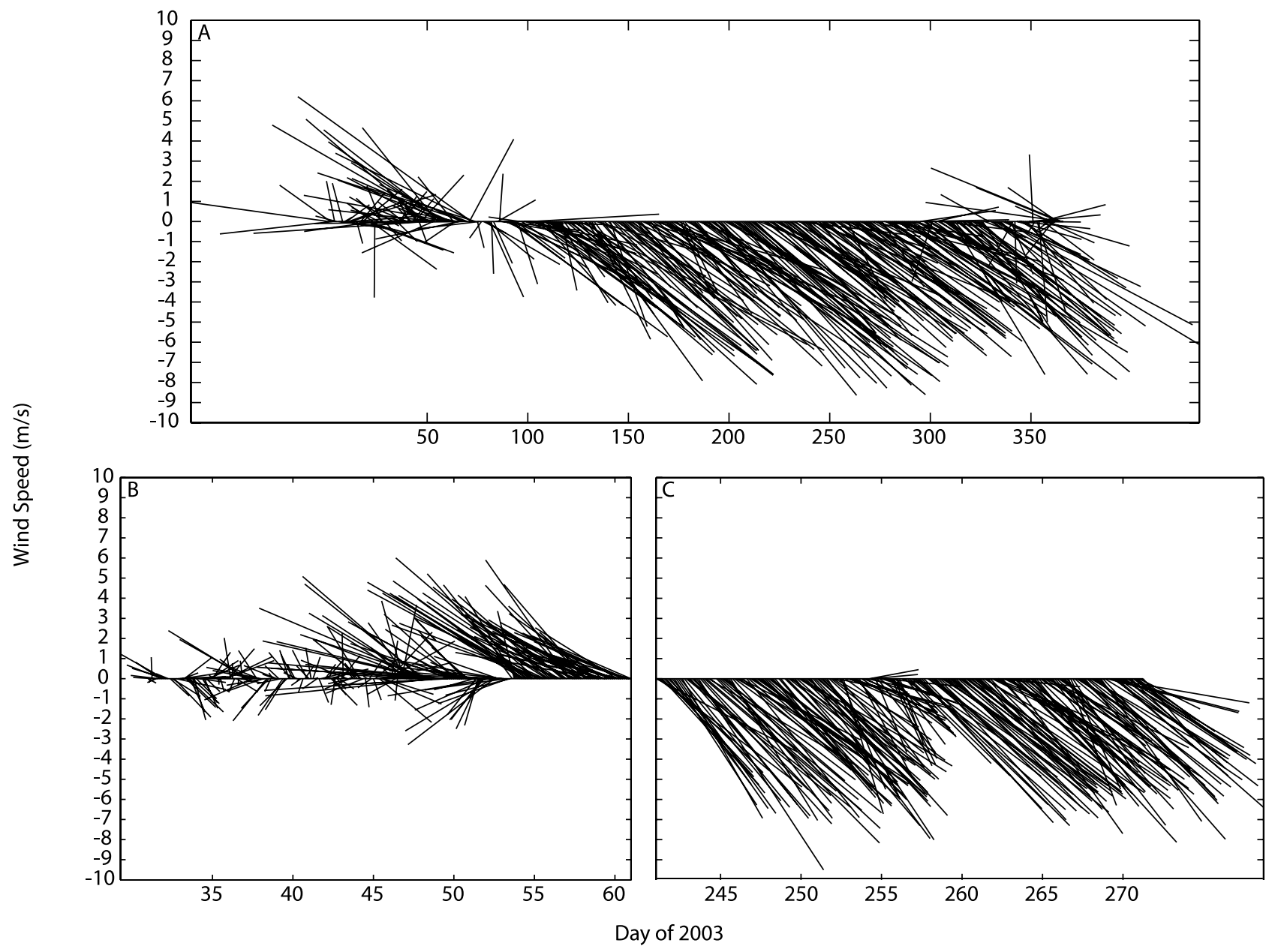

Figure 2. Feather plot of daily winds at $9^{\circ} \mathrm{S}, 144^{\circ} \mathrm{E}$ predicted by the Navy Operational Global Atmospheric Prediction System (NOGAPS) at noon local time for the first sigma level above the sea surface. (a) Complete time series starting at 00001 January 2003, (b) monsoon conditions, and (c) trade wind conditions. Rays point in direction from which wind is blowing.

al. $[1995 \mathrm{~b}]$ calculated flow patterns on the GOP shelf using a circulation model developed for Bowden Reef, which is located on the east coast of the Cape York Peninsula [Wolanski and King, 1990]. Simulations were conducted on a three-dimensional grid using the CSC, river runoff, and $\mathrm{M}_{2}$ tidal variations as boundary conditions. Local winds were used in some tests as surface boundary conditions. Although a pioneering effort, the predicted flows appear to be compromised by the coarse grid $(12.5 \mathrm{~km})$ and boundary effects.

[15] Hemer et al. [2004] attempted to overcome these earlier limitations by employing the MECO model developed by Australia's Commonwealth Scientific and Industrial Research Organization (CSIRO). They increased the grid resolution, expanded the model domain, and incorporated higher-resolution bathymetry. Their open boundary conditions included both tidal and subtidal flow with nine tidal components $\left(\mathrm{M}_{2}, \mathrm{~S}_{2}, \mathrm{~K}_{1}, \mathrm{O}_{1}, \mathrm{~N}_{2}, \mathrm{Q}_{1}, \mathrm{~S}_{\mathrm{a}}, \mathrm{S}\right.$ sa, $\left.\mathrm{M}_{\mathrm{sf}}\right)$ and dynamic heights calculated from temperature and salinity climatologies for the region. Atmospheric pressure and wind speed were interpolated from 6-hourly NCEP-NCAR data. Although the model did not include the Coral Sea Current and freshwater input from rivers other than the Fly, the model predictions contain several trends relevant to the current study. Mean depth-integrated currents were predicted to flow uniformly clockwise $(\mathrm{CW})$ over the Holocene clinothem during the monsoons, whereas the pattern during the trade winds shows a convergence of flow over the clinothem north of the Fly River mouth due to a counterclockwise $(\mathrm{CCW})$ gyre in the $\mathrm{NE}$ and a $\mathrm{CW}$ gyre closer to the Fly River. Maximum bed stress vectors, which approximate bed load transport, were predicted to be seaward over the northeastern half of the clinothem and shoreward to the southwest, regardless of season. The zone of seaward transport expanded southward during the trade winds. These predictions from Hemer et al. [2004] will be compared to those from this study in a later section.

\section{Methods}

[16] As part of the NSF-MARGINS Source-to-Sink Initiative, current observations were combined with model simulations of the Gulf of Papua focus site during calendar years 2003 and 2004 in order to understand better the processes that have created the Holocene clinothem. Despite the moderate El Niño condition that existed in 2002-2003 
Table 1. Tripod and Mooring Locations

\begin{tabular}{lcccc}
\hline $\begin{array}{c}\text { Site } \\
\text { Name }\end{array}$ & $\begin{array}{c}\text { Latitude, } \\
\text { deg }\end{array}$ & $\begin{array}{c}\text { Longitude, } \\
\text { deg }\end{array}$ & Date In & Date Out \\
\hline T8-16 & 8.58 & 143.96 & 8 Jan 2003 & 15 Jan 2003 \\
T13-20 & 8.30 & 143.26 & 24 Aug 2003 & 20 Sep 2003 \\
T13-30 & 8.34 & 144.30 & 24 Aug 2003 & 20 Sep 2003 \\
T8-16 & 8.58 & 143.96 & 29 Aug 2003 & 30 Sep 2003 \\
T8-35 & 8.72 & 144.04 & 24 Aug 2003 & 15 Sep 2003 \\
T4-70 & 9.12 & 144.41 & 25 Aug 2003 & 28 Sep 2003 \\
T13-20 & 8.30 & 144.26 & 12 Jan 2004 & 7 Feb 2004 \\
T10-20 & 8.59 & 144.18 & 11 Jan 2004 & 9 Feb 2004 \\
T8-16 & 8.58 & 143.96 & 11 Jan 2004 & 12 Feb 2004 \\
T4-70 & 9.12 & 144.41 & 12 Jan 2004 & 11 Feb 2004 \\
\hline
\end{tabular}

with below average river discharge [Ogston et al., 2008], the observations and model results presented here are generally consistent with observations acquired during non-El Niño years by earlier workers.

\subsection{Observations}

[17] Time series data were obtained at four locations near the mouth of the Fly River during portions of JanuaryFebruary 2004, April-May 2004, and August-September 2003 using bottom boundary layer tripods and a mooring equipped with sensors to measure water surface elevation and water column and boundary layer currents. Sensors included an upward looking acoustic Doppler current profiler (ADCP), acoustic Doppler velocimeter (ADV), and S4A current meter. Instrument locations and deployment durations are given in Figure 1 and Table 1. Water column profiling of salinity, temperature, and suspended-sediment concentration was also performed in a spatial grid. The observed time series data at the instrument sites were processed to extract the tidal constituents and a low-pass filter was used to extract residual currents. The low-pass filter employed was the PL33 filter with a filter halfamplitude period equal to $33 \mathrm{~h}$ and half power period of $38 \mathrm{~h}$. For a description of the observational campaign, instrument capabilities, and treatment of the observations see Martin et al. [2008].

\subsection{Model Simulations}

[18] Flows in the Gulf of Papua during calendar year 2003 were computed using the Navy Coastal Ocean Model (NCOM), a three-dimensional primitive equation hydrodynamic model that solves the hydrostatic, incompressible, and Boussinesq approximations to the conservation equations [Martin, 2000]. The density equation is computed using the Mellor [1991] formulations. The horizontal interlayer friction terms are calculated using the Laplacian form of horizontal mixing with the mixing coefficients computed via the Smagorinsky [1963] scheme. Vertical mixing is computed using the Mellor-Yamada Level 2.5 parameterization [Mellor and Yamada, 1982].

[19] The model equations are solved on the Arakawa $\mathrm{C}$ grid. The horizontal grid is orthogonal curvilinear in plan view and uses a hybrid sigma $-z$ grid in the vertical. Spatial differences and interpolations, and upwind advection for momentum and scalar fields are second order. Temporal differencing is leapfrog with an Asselin [1972] filter to suppress time splitting. The continuity and vertical mixing equations are solved implicitly; the other terms are treated explicitly.
[20] The simulation domain (Figure 1) includes a portion of the Gulf of Carpentaria, Torres Strait, Gulf of Papua, and the northern Coral Sea. The domain is discretized into blocks of $0.03^{\circ}$ in latitude and longitude. In the vertical there are 10 sigma levels equally spaced between the water surface and the local bottom or $101.43 \mathrm{~m}$, whichever is smaller, and fixed $z$ levels below this depth to the maximum depth in the domain. Three-dimensional prognostic variables are calculated at all $z$ and sigma levels above the local water depth, then interpolated to a user-specified grid for analysis.

[21] This GOP simulation incorporates more complex forcing than previous studies. The GOP model domain (Figure 1) is chosen to keep open boundaries far removed from the Gulf of Papua. Subtidal flows at open boundary cells are interpolated from the $12 \mathrm{hr}$ output of the east Asian seas implementation of NCOM (EAS16) [Keen et al., 2006]. Eight tidal constituents at the open boundaries are computed using the Oregon State University Tidal Inversion System (OTIS) [Egbert and Erofeeva, 2002]. A volume source/sink term in the mass conservation equation is used to specify river and runoff inflows. Five rivers are included in this simulation (Figure 1). Water enters the computational domain at rates equal to their mean annual discharges, which are for the Fly southern channel, $3000 \mathrm{~m}^{3} \mathrm{~s}^{-1}$, Fly far northern channel, $4000 \mathrm{~m}^{3} \mathrm{~s}^{-1}$, Bamu, $2000 \mathrm{~m}^{3} \mathrm{~s}^{-1}$, Turama, $2000 \mathrm{~m}^{3} \mathrm{~s}^{-1}$, Purari, $2000 \mathrm{~m}^{3} \mathrm{~s}^{-1}$, and Kikori, $2000 \mathrm{~m}^{3} \mathrm{~s}^{-1}$ [Salomons and Eagle, 1990; Wolanski et al., 1984]. River input enters the top four layers in equal proportion and at a constant temperature of $20^{\circ}$ and salinity of 5. Surface boundary conditions include surface wind stresses and atmospheric pressures for the momentum equations interpolated from the Navy Operational Global Atmospheric Prediction System (NOGAPS) [Bayler and Lewit, 1992]. Fluxes of heat and salt at the bottom are set to zero. Bottom stresses are computed by a quadratic drag law in which the coefficient of drag, $\mathrm{Cd}=(0.4 / \ln (30 \mathrm{z})$ $0.01))^{2}$ with a minimum of 0.0025 .

[22] The EAS16 model, which supplies both initial and boundary conditions to the GOP model, computes temperature, salinity, flow velocities, and water surface elevations (minus the tides) on a $1 / 16^{\circ}(6.9 \mathrm{~km})$ spherical grid. The EAS16 model assimilates monthly mean discharges for 51 rivers in its domain, and synthetic temperature and salinity profiles and altimetry. Surface boundary conditions for EAS16 consist of heat fluxes, precipitation, surface pressure, and wind stresses from global NOGAPS at a $1^{\circ}$ node spacing. Open boundary conditions for EAS16 are provided by the global NCOM model [Barron et al., 2004].

[23] Model predictions of velocities, water surface elevations, salinities, and temperatures were computed every $5 \mathrm{~min}$ and saved every $3 \mathrm{~h}$ over the interval 0300 local time on 1 January 2003 to 0000 on 1 January 2004. Ellipses of predicted mean tidal currents were computed over a lunar month of model output. Residual or subtidal currents were computed using the same low-pass filter applied to the observations.

\subsection{Validation of the GOP Model}

[24] To gauge the accuracy of the model predictions we first compare model estimates of water surface elevations to values observed at two instrument sites (T4-70 and T8-16) on the Holocene clinothem during late August to early 
T4-70

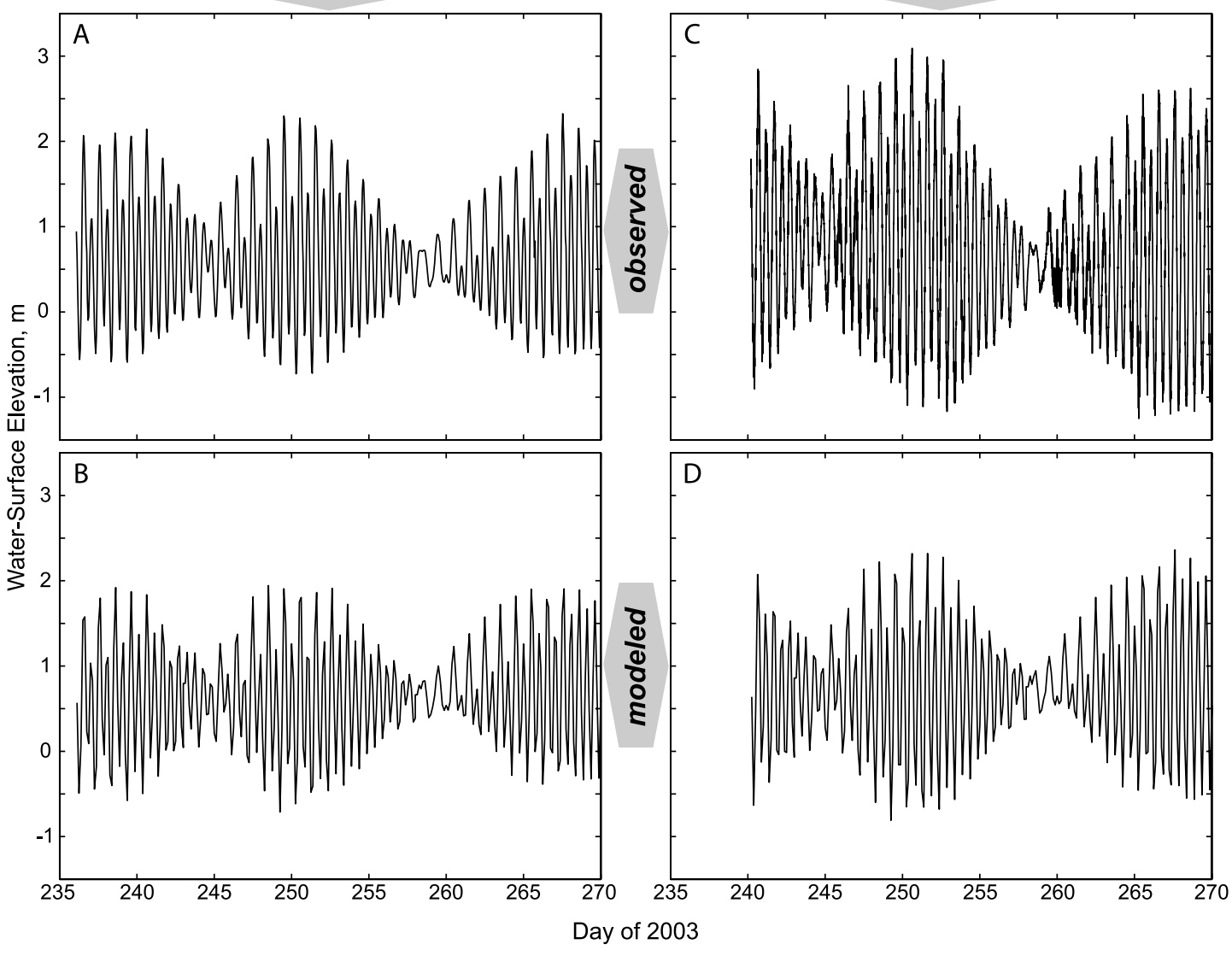

Figure 3. Observed and modeled water surface elevations from 25 August to 25 September 2003 at observation locations and nearest NCOM grid node (a) observed at T4-70 $\left(9^{\circ} 07.482^{\prime}, 144^{\circ} 24.545^{\prime}\right)$, (b) modeled at NCOM node nearest T4-70, (c) observed at T8-16 $\left(8^{\circ} 34.535^{\prime}, 143^{\circ} 57.817^{\prime}\right)$, and (d) modeled at NCOM node nearest T8-16.

September 2003 (Figure 3). By inspection, there is a good agreement between the observed and predicted phases, but the model predicts smaller amplitudes. A more robust comparison is provided by comparing predicted tidal constituents of water surface elevations to those observed (Table 2). Predicted amplitudes and phases of tidal constituents are generally no more than $20 \%$ different from observed. The NCOM errors in $\mathrm{M}_{2}$ amplitude and phase are similar to those reported by Hemer et al. [2004] in their modeling study of the Torres Strait region using MECO, but the NCOM errors show an improvement in covariance. The slopes of the regression lines between observed and predicted water surface elevations at three sites (Table 2) range from 0.78 to 0.94 with Pearson product moment correlation coefficients $(r)$ equal to 0.79 to 0.96 , indicating that NCOM is slightly underpredicting the stage. The errors are largest during spring tides. The extrema observed near the Fly delta (Figure 3) and within the distributaries [Dalrymple et al., 2003; Wolanski and Eagle, 1991] were not captured by NCOM because the grid did not resolve the Fly delta distributaries.

[25] Residual circulation is of particular interest in the GOP because it defines the net sediment transport directions. Model predictions and observations of time-averaged vertical velocity profiles at two sites during the trade winds (Figure 4) compare favorably. Predicted and observed,
Table 2. Comparison of Tidal Constituents of Water Surface Elevation for Sites in the GOP

\begin{tabular}{|c|c|c|c|c|c|}
\hline & $\mathrm{M}_{2}$ & $\mathrm{~S}_{2}$ & $\mathrm{~N}_{2}$ & $\mathrm{~K}_{1}$ & $\mathrm{O}_{1}$ \\
\hline \multicolumn{6}{|c|}{$T 4-70^{\mathrm{b}}$} \\
\hline Observed amplitude & 0.62 & 0.45 & 0.17 & 0.31 & 0.17 \\
\hline Observed phase & 44 & 59 & 33 & 115 & 353 \\
\hline Modeled amplitude & 0.60 & 0.44 & 0.19 & 0.24 & 0.16 \\
\hline Modeled phase & 39 & 51 & 33 & 116 & 358 \\
\hline \multicolumn{6}{|c|}{ T8-16 (Monsoon $^{\mathrm{c}}$} \\
\hline Observed amplitude & 0.74 & 0.31 & 0.13 & 0.39 & 0.12 \\
\hline Observed phase & 63 & 79 & 94 & 100 & 23 \\
\hline Modeled amplitude & 0.82 & 0.29 & 0.20 & 0.42 & 0.12 \\
\hline Modeled phase & 49 & 74 & 84 & 101 & 11 \\
\hline \multicolumn{6}{|c|}{ T8-16 (Trade $)^{\mathrm{d}}$} \\
\hline Observed amplitude & 0.88 & 0.66 & 0.23 & 0.31 & 0.16 \\
\hline Observed phase & 60 & 77 & 55 & 117 & 2 \\
\hline Modeled amplitude & 0.75 & 0.56 & 0.23 & 0.32 & 0.17 \\
\hline Modeled phase & 46 & 59 & 42 & 118 & 3 \\
\hline
\end{tabular}

${ }^{a}$ See Figure 1 and Table 1 for locations. Amplitudes are given in meters; phases given in degrees $\mathrm{CW}$ from north. Tidal constituents are $\mathrm{M}_{2}(12.42 \mathrm{~h})$, $\mathrm{S}_{2}(12.00 \mathrm{~h}), \mathrm{N}_{2}(12.66 \mathrm{~h}), \mathrm{K}_{1}(23.93 \mathrm{~h})$, and $\mathrm{O}_{1}(25.82 \mathrm{~h})$. Slope of regression line, $m$, and Pearson product moment correlation coefficient, $r$, between observed and predicted water surface elevations over $39 \mathrm{~d}$ (274 points), $32 \mathrm{~d}$ (259 points), and $7 \mathrm{~d}$ (56 points) for T4-70, T8-16 (monsoon), and T8-16 (trade), respectively.

${ }^{\mathrm{b}}$ Here $m=0.91, r=0.96$.

${ }^{\mathrm{c}}$ Here $m=0.94, r=0.79$.

${ }^{\mathrm{d}}$ Here $m=0.78, r=0.93$. 


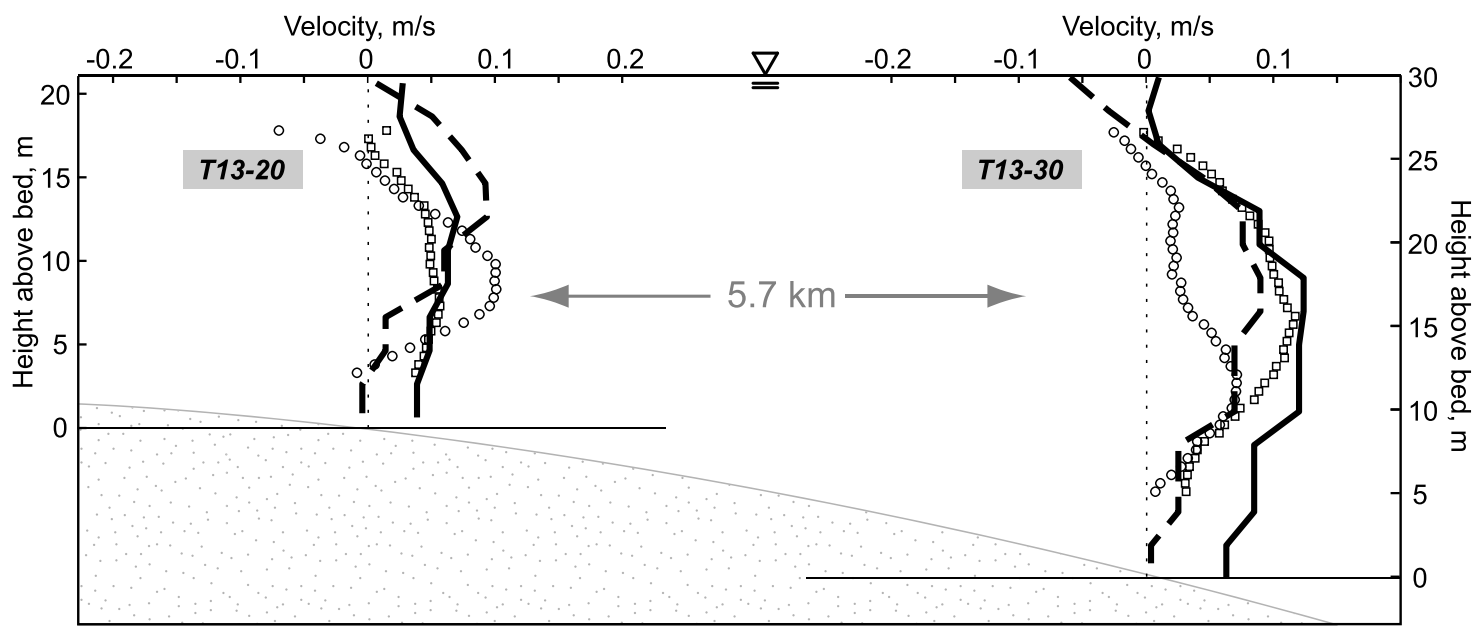

Figure 4. ADCP-observed versus NCOM-predicted vertical velocity profiles at sites T13-20 (water depth $20 \mathrm{~m}$ ), and T13-30 (water depth $30 \mathrm{~m}$ ), both averaged over interval from 24 August to 20 September 2003 in the trade wind season. Observed velocities are denoted by circles $(u)$ and squares $(v)$, and NCOMpredicted velocities are denoted by dashed line $(u)$ and solid line $(v)$. Positive $u$ and $v$ velocities are east and north, respectively. NCOM predicts the general shapes and relative magnitudes well.

vertically averaged, low-pass-filtered velocities at site T13-20 (Figure 5) compare less favorably, although the correlation is still apparent. The errors probably arise from the coarseness of the computation and bathymetric meshes, with errors in estimating bottom roughness and daily freshwater influxes contributing to a lesser extent. On balance, we conclude that the model adequately captures the general magnitudes and directions of coastal flows in the gulf.

\section{Observations and Interpretations}

[26] In the following section, the Gulf of Papua is divided into three regions, each marking a separate part

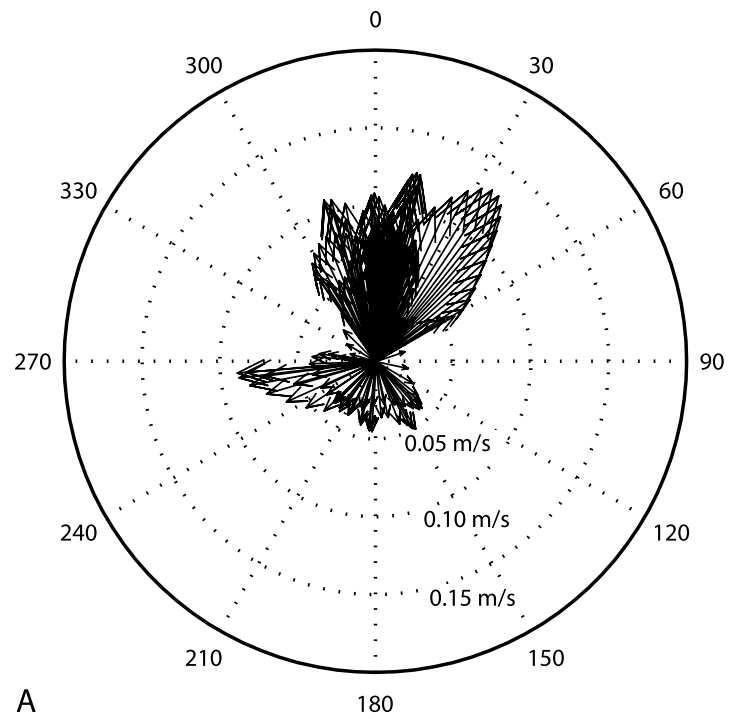

A

observed of the Holocene clinothem. The "topset" region refers to the seabed extending from the shoreline to the clinoform rollover at 20-30 m water depth, the foreset refers to the more steeply dipping surface between the 20 and $60 \mathrm{~m}$ isobaths, and the outer shelf refers to the corrugated surface seaward of the $60 \mathrm{~m}$ isobath. For each region we discuss both observed and NCOM-predicted surface and near-bed flows. Surface flows for the observations are estimated by the vertical average of the upper 1 to $10 \mathrm{~m}$, depending upon water depth, and for the model results are estimated by the vertical average velocity over all but the lowest $2 \mathrm{~m}$. Near-bed flows are represented by an average velocity observed over the lowermost $2 \mathrm{~m}$ of the water

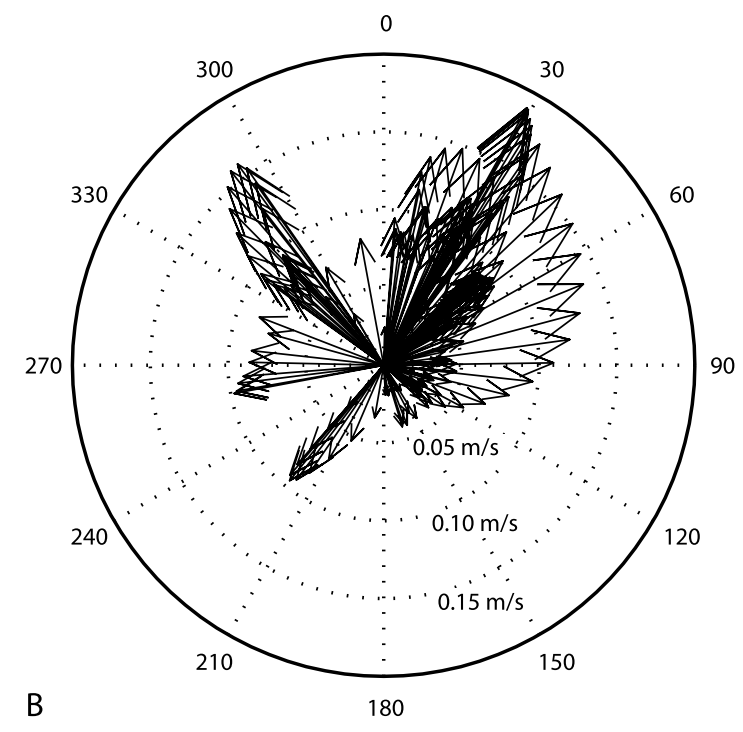

modeled

Figure 5. Depth-averaged, low-pass-filtered velocities at location T13-30 and nearby NCOM node $(140,144)$ sampled every $3 \mathrm{~h}$ over the interval 24 August to 20 September 2003. Azimuth is in degrees clockwise from north; vector magnitude is in $\mathrm{m} \mathrm{s}^{-1}$. Predicted filtered velocities are about $30 \%$ larger, and variance is greater than observed, but trends are similar. 

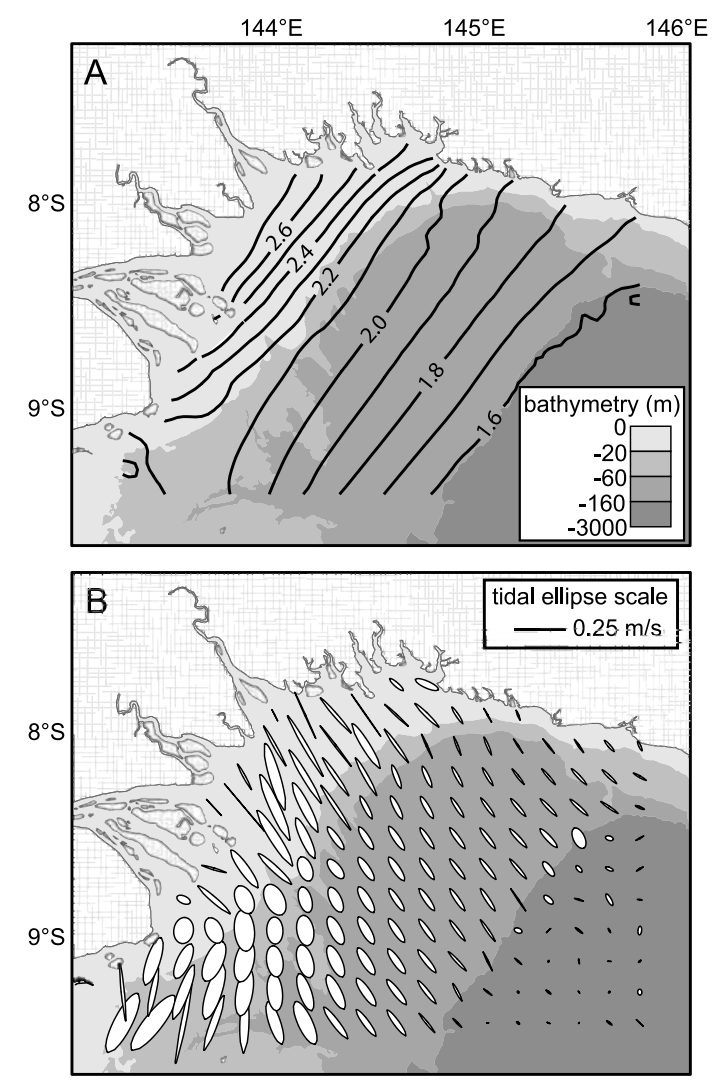

Figure 6. NCOM-predicted tides in Gulf of Papua. (a) Predicted average spring tidal ranges during trade winds. Contours represent mean range over $7 \mathrm{~d}$ spanning highest spring tides from 22 to 28 September 2003. Predicted ranges are microtidal seaward and mesotidal on the clinoform topset. (b) M2 tidal ellipses averaged over a lunar month from 1 to 29 September 2003. Tidal flows over the clinothem are generally onshore/offshore, slightly rotary, and $\sim 0.7 \mathrm{~m} \mathrm{~s}^{-1}$.

column, and for the model results are estimated by the velocity from the bottommost interpolation level of NCOM (approximately $1 \mathrm{~m}$ above the bed in less than $20 \mathrm{~m}$ water). To differentiate data collected in the field from model results we use the terms observed and predicted, respectively. In addition to the figures presented here, dynamic content (Movie $1^{1}$ ) is provided that consists of movies of surface and near-bed current velocity vectors computed every $3 \mathrm{~h}$ by NCOM for selected months during 2003.

\subsection{Tidal Stages and Currents}

[27] Tides in the GOP have a mixed semidiurnal character with a strong spring/neap variation (Figure 3). NCOMpredicted mean tidal ranges for $7 \mathrm{~d}$ spanning the highest spring tides from 22 to 28 September 2003 (Figures 6a and 7) increase from $1.6 \mathrm{~m}$ on the outer shelf to $2.7 \mathrm{~m}$ near the northwest coast of the gulf, because of amplification over the topset. The $\mathrm{M}_{2}$ tidal ellipses computed from the NCOM-predicted currents (Figure $6 \mathrm{~b}$ ) reveal a regional

\footnotetext{
${ }^{1}$ Animations are available in the HTML.
}

pattern of convergence to the northwest with mean tidal currents of $0.6-0.8 \mathrm{~m} \mathrm{~s}^{-1}$ almost everywhere.

[28] Observed near-bed tidal currents reached $0.76 \mathrm{~m} \mathrm{~s}^{-1}$ on the outer topset during spring tides, and $0.64 \mathrm{~m} \mathrm{~s}^{-1}$ on the upper foreset; in general, tidal currents at instrument locations on the shallower topset were approximately $16 \%$ greater than those on the upper foreset. Surface tidal currents peaked at $\sim 1.50 \mathrm{~m} \mathrm{~s}^{-1}$ and had a more rotary character than those at the seabed. Near-bed tidal currents observed at equal water depths (Table 3 ) increased slightly in magnitude to the NE (maximum spring flood currents at T13-20 were $0.76 \mathrm{~m} \mathrm{~s}^{-1}$, whereas at T10-20 they were $0.72 \mathrm{~m} \mathrm{~s}^{-1}$ ). Within a reentrant on the foreset called Umuda Valley (a linear depression east of the Fly River delta at station T8-35 in Figure 1) [Martin et al., 2008], maximum spring tidal currents were $0.63 \mathrm{~m} \mathrm{~s}^{-1}$ at $35 \mathrm{~m}$ water depth and $0.86 \mathrm{~m} \mathrm{~s}^{-1}$ at $16 \mathrm{~m}$ water depth. Nearbed tidal ellipses observed from tripods on the outer clinoform topset (T8-18, T10-20, T13-20) and upper foreset (T4-70, T8-35, T13-30) during both climatological seasons (Table 3 ) reveal across-shelf directed tidal currents, similar to predicted ellipses (Figure $6 \mathrm{~b}$ ).

[29] A simple harmonic analysis of both observations and model predictions shows that the $\mathrm{M}_{2}$ tide is the dominant constituent, with $\mathrm{S}_{2}$ playing a subordinate role (Tables 2 and 3). This analysis also shows that on the clinoform topset, the strongest observed tides occurred within Umuda Valley because of the convergence of the tidal wave as it enters the deltaic channels. $\mathrm{M}_{2}$ tidal currents nearby at T10-20 were significantly weaker and less focused in the shore-perpendicular direction with velocities almost half as strong as those observed in Umuda Valley. But as Figure 6b shows, near-bed tidal flows on the clinoform topset generally are predicted to have maximum currents of $0.6-0.8 \mathrm{~m} \mathrm{~s}^{-1}$ almost everywhere. On the shelf seaward of the clinothem in $70 \mathrm{~m}$ of water (T4-70), near-bed tidal currents are significantly smaller (Figure 6b and Table 3) with both observed and predicted currents reaching a maximum of $0.38 \mathrm{~m} \mathrm{~s}^{-1}$ at the mooring site. Predicted tidal flow on the outer shelf in depths greater than $70 \mathrm{~m}$ remains primarily across shore, with mean currents less than $0.1 \mathrm{~m} \mathrm{~s}^{-1}$. The much weaker tidal flow there suggests that subtidal currents will play an increased role in moving sediment across this region to the deep ocean.

\subsection{Low-Frequency Currents}

[30] The strong tidal currents provide high shear stresses to entrain sediment but obscure the significantly weaker low-frequency, or residual currents that may provide the sediment's net motion. Estimates of the net motion of fluid parcels, and inferred net motion of sediment, are shown by observed (Figures $8 \mathrm{a}-8 \mathrm{~d}$ and $9 \mathrm{a}-9 \mathrm{~d}$ ) and NCOM-predicted (Figures $8 \mathrm{e}-8 \mathrm{~h}$ and $9 \mathrm{e}-9 \mathrm{~h}$ ) progressive vector diagrams and by observed (Table 4 and Figures 7 and 10) and predicted (Figures 11 and 12 and dynamic content) lowpass-filtered observations.

[31] Three general circulation patterns are observed in the model results, corresponding to combinations of winds and the Coral Sea Current. Winds over the Gulf of Papua take on one of three states: monsoon, trade winds, or transition (Figure 2). The position of the Coral Sea Current relative to shore also varies seasonally, both in strength and location, 
TRADE-WIND SEASON - T13-20

a) Wind Speed and Direction - from R/V Melville

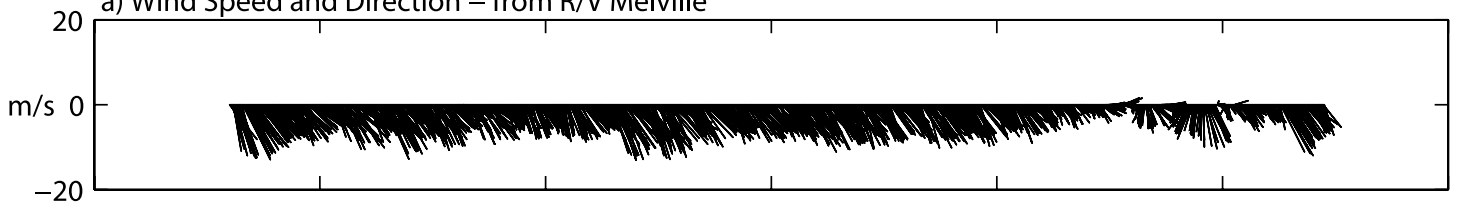

b) Water Depth
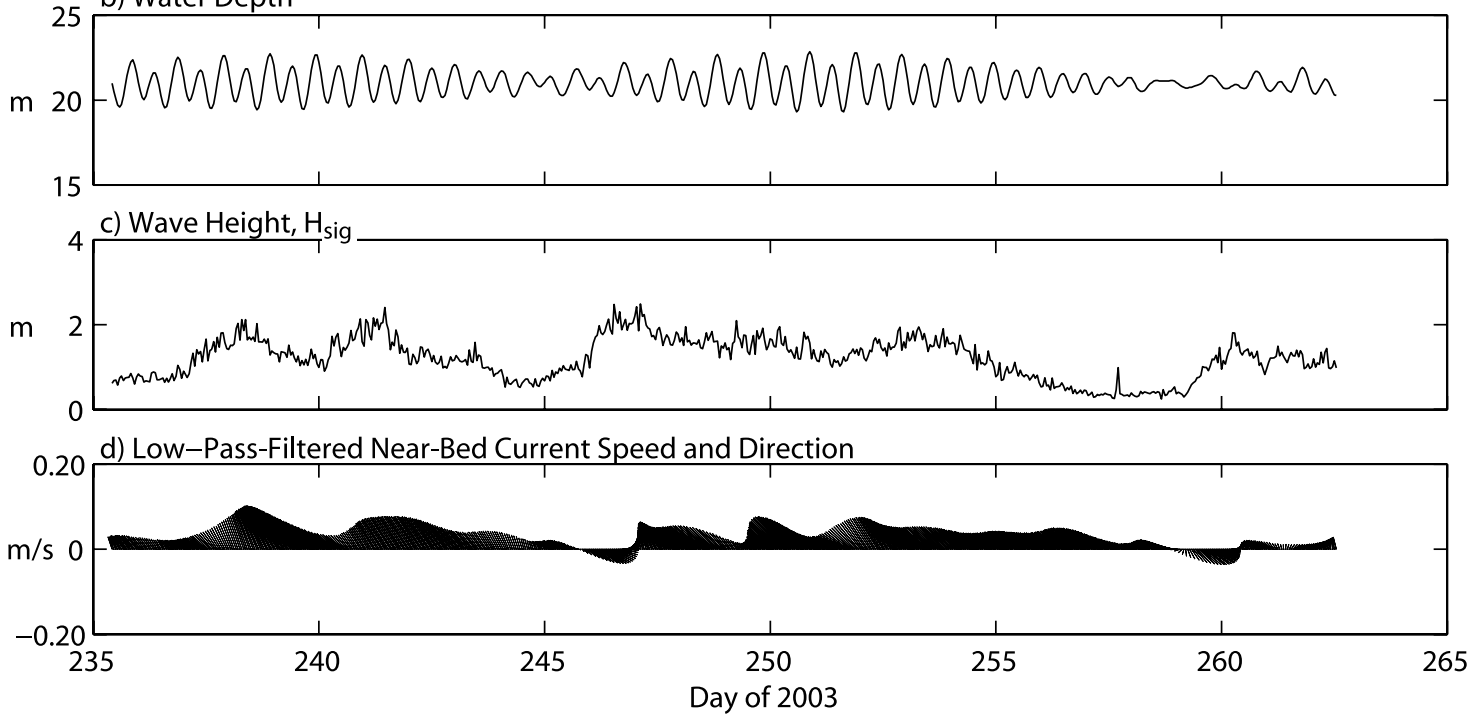

Figure 7. Data collected at site T13-20 (see Figure 1 for location). (a) Wind speed and direction (arrows point in direction from which wind is blowing). (b) Water depth. (c) Wave height. (d) Low-pass-filtered near-bed currents (arrows point in direction of flow). Low-pass-filtered currents at this site during the trade winds generally flow to the NW at speeds of $0.03-0.05 \mathrm{~m} \mathrm{~s}^{-1}$.

thus modifying the shear zone between the Coral Sea Current and the shelf waters of the GOP. Because the transition periods are relatively brief, we do not report on them here.

\subsection{Monsoon Wind Conditions}

[32] During calendar year 2003, the monsoon season lasted until about 1 March 2003 (Figure 2). Winds were generally weak $\left(\sim 1 \mathrm{~m} \mathrm{~s}^{-1}\right)$ and from the NW, with stronger breakouts $\left(\sim 4 \mathrm{~m} \mathrm{~s}^{-1}\right)$ occurring sporadically. The CSC was weak and located primarily seaward of the shelf edge, creating a shear zone between it and the shelf waters. The $28 \mathrm{~d}$ of February are representative of monsoon conditions during calendar year 2003 and are used here to typify currents during this climate state.

[33] The predicted low-frequency monsoonal surface flow (Figure 11a) on the topset is generally seaward with magnitudes of $\sim 0.05 \mathrm{~m} \mathrm{~s}^{-1}$. The weak currents reflect a lack of strong baroclinic forcing and seaward directed wind stresses. River plumes show up however, as increased surface currents in front of the far northern distributary of the Fly River and in front of the Purari and Kikori Rivers. Mean currents along the northeastern shelf are an exception to this pattern, being dominated by the common occurrence of anticyclonic (CCW) gyres that occur between the shelf waters and the CSC.

[34] Point observations confirm these predictions. For example, at tripod site T13-20 near the rollover (Table 4 and Figure 10a) the mean surface flow during late January to early February 2004 was about $0.08 \mathrm{~m} \mathrm{~s}^{-1}$ and the maximum flow was only $0.41 \mathrm{~m} \mathrm{~s}^{-1}$, both directed seaward and to the NE. At T10-20 farther south, mean currents were of similar strength but in the mean were directed NE, parallel to isobaths. These shore-parallel residual flows alternated between $\mathrm{SW}$ and $\mathrm{NE}$ and averaged $0.06 \mathrm{~m} \mathrm{~s}^{-1}$ to the NE. The periods of strong $\left(0.41 \mathrm{~m} \mathrm{~s}^{-1}\right) \mathrm{SW}$ flows were associated with monsoonal breakouts.

Table 3. Observed Near-Bed Tidal Velocity Constituents for the $\mathrm{M}_{2}$ and $\mathrm{S}_{2}$ Tides During the Monsoon Season

\begin{tabular}{|c|c|c|c|c|}
\hline $\begin{array}{c}\text { Location/Tidal } \\
\text { Constituent }\end{array}$ & $\begin{array}{c}\text { Maximum } \\
\text { Spring Tidal } \\
\text { Current, } \mathrm{m} \mathrm{s}^{-1}\end{array}$ & $\begin{array}{c}\text { Major } \\
\text { Axis, } \mathrm{m} \mathrm{s}^{-1}\end{array}$ & $\begin{array}{c}\text { Minor } \\
\text { Axis, } \mathrm{m} \mathrm{s}^{-1}\end{array}$ & $\begin{array}{c}\mathrm{CCW} \\
\text { Inclination } \\
\text { From East } \\
\text { Axis, deg }\end{array}$ \\
\hline T13-20 & 0.76 & & & \\
\hline $\mathrm{M}_{2}$ & & 0.39 & 0.003 & 152 \\
\hline $\mathrm{S}_{2}$ & & 0.2 & 0.02 & 152 \\
\hline T13-30 & 0.64 & & & \\
\hline $\mathrm{M}_{2}$ & & 0.33 & 0.01 & 139 \\
\hline $\mathrm{S}_{2}$ & & 0.24 & 0.01 & 138 \\
\hline T10-20 & 0.72 & & & \\
\hline $\mathrm{M}_{2}$ & & 0.25 & 0.04 & 142 \\
\hline $\mathrm{S}_{2}$ & & 0.12 & 0.04 & 140 \\
\hline T8-18 & 0.86 & & & \\
\hline $\mathrm{M}_{2}$ & & 0.49 & 0.06 & 131 \\
\hline $\mathrm{S}_{2}$ & & 0.22 & 0.02 & 140 \\
\hline T8-35 & 0.63 & & & \\
\hline T4-70 & 0.38 & & & \\
\hline $\mathrm{M}_{2}$ & & 0.1 & 0.003 & 65 \\
\hline $\mathrm{S}_{2}$ & & 0.04 & 0.003 & 83 \\
\hline
\end{tabular}



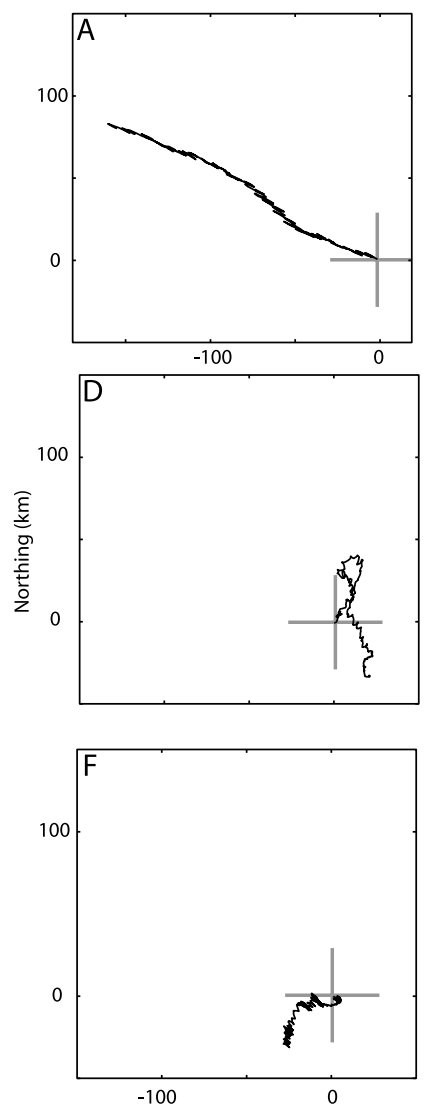
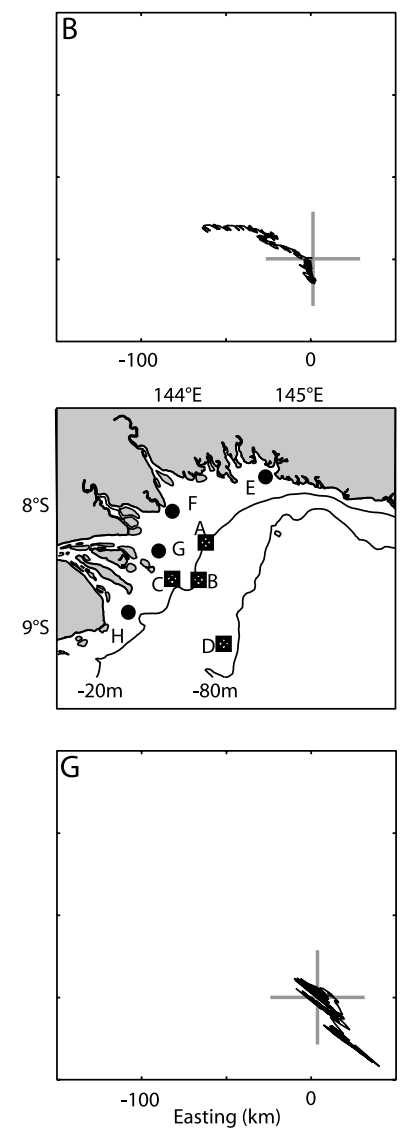
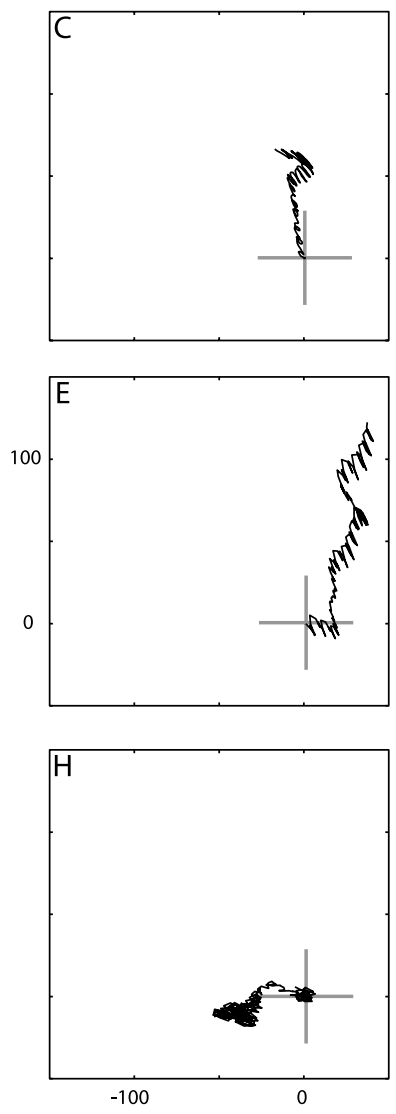

Figure 8. $(\mathrm{a}-\mathrm{d})$ Observed and $(\mathrm{e}-\mathrm{h}) \mathrm{NCOM}$-predicted progressive vectors of near-bed currents during monsoon wind conditions (1-27 February 2003) at various sites on the Holocene clinoform (see inset and Figure 1 for locations): (a) TA13-20; (b) T10-20; (c)T8-16; (d) 4-70; (e) NCOM node 161,180; (f) NCOM node 153,155; (g) NCOM node 140,151; and (h) NCOM node 123,126.

[35] Over the foreset the predicted surface flow becomes increasingly dominated by the CSC, because an eddy on the order of $100 \mathrm{~km}$ in diameter develops on the north side of the GOP and remains a persistent feature (Figure 11). This eddy is associated with a water surface elevation anomaly of about $+0.2 \mathrm{~m}$. Along-isobath flow associated with this eddy passes over the foreset and bottomset at low-pass-filtered speeds of $0.1-0.2 \mathrm{~m} \mathrm{~s}^{-1}$ in a SW direction until it reaches the Fly River, where it turns seaward with speeds up to $0.1 \mathrm{~m} \mathrm{~s}^{-1}$.

[36] Predicted surface flow over the outer shelf (Figure 11a) exceeds $0.1 \mathrm{~m} \mathrm{~s}^{-1}$ and is generally NE directed as also reported by Wolanski et al. [1995b]. Occasionally however, these outershelf flows increase in strength and trend to the SE, coincident with the wind breakouts typical of the monsoon season. Seaward of the $300 \mathrm{~m}$ bathymetric contour lies the CSC flowing to the NE.

[37] Predicted (Figures $8 \mathrm{e}-8 \mathrm{~h}$ and $11 \mathrm{~b}$ ) and observed (Figure 10) low-pass-filtered near-bed flows during the monsoons are weaker than flows at the surface and quite different in orientation. Near-bed flows on the topset move generally landward, with areas of intensification near the river mouths. Near-bed observed residual currents at T8-16, T13-20, and T13-30 ranged between 0.025 and $0.07 \mathrm{~m} \mathrm{~s}^{-1}$ landward (Table 4). At T13-20 a bottom layer of about $5 \mathrm{~m}$ thickness was observed (Figure 10). As expected, the currents peaked in intensity during spring tides and periods of strong, seaward directed winds. In general, observed near-bed low-frequency flows resulted in enhanced flood currents and diminished ebb, thus creating a resultant mean residual of $0.07 \mathrm{~m} \mathrm{~s}^{-1}$ landward. Shore-parallel residual flows alternated between SW and NE, with each direction persisting for several days. These observed flows were generally weak $\left(0.02 \mathrm{~m} \mathrm{~s}^{-1}\right)$ and in the net, directed to the SW; however during wind breakouts associated with waves $(0.96 \mathrm{~m})$ they were stronger $\left(0.04 \mathrm{~m} \mathrm{~s}^{-1}\right)$ and NE. The overall pattern of landward bottom flows and seaward surface flows likely represents coastal upwelling due to seaward wind stresses and entrainment of shelf waters by riverine surface flows.

[38] On the foreset the predicted residual near-bed flows (Figure 11b) are larger in magnitude and directed obliquely landward and to the SW, with the along-isobath component similar to the surface flows. When encountering the steep foreset, they deflect to the west and climb the face, while maintaining their intensity $\left(0.04 \mathrm{~m} \mathrm{~s}^{-1}\right)$. Flows at the bed on the outer shelf (Figure 11) are only slightly weaker $\left(0.03 \mathrm{~m} \mathrm{~s}^{-1}\right)$ and flow contour parallel to the SW.

\subsection{Trade Wind Conditions}

[39] The trade wind season (April to December 2003) is characterized by strong sustained winds from the SW (Figure 2c) and a much stronger CSC $\left(\sim 12 \mathrm{~m} \mathrm{~s}^{-1}\right)$. The 

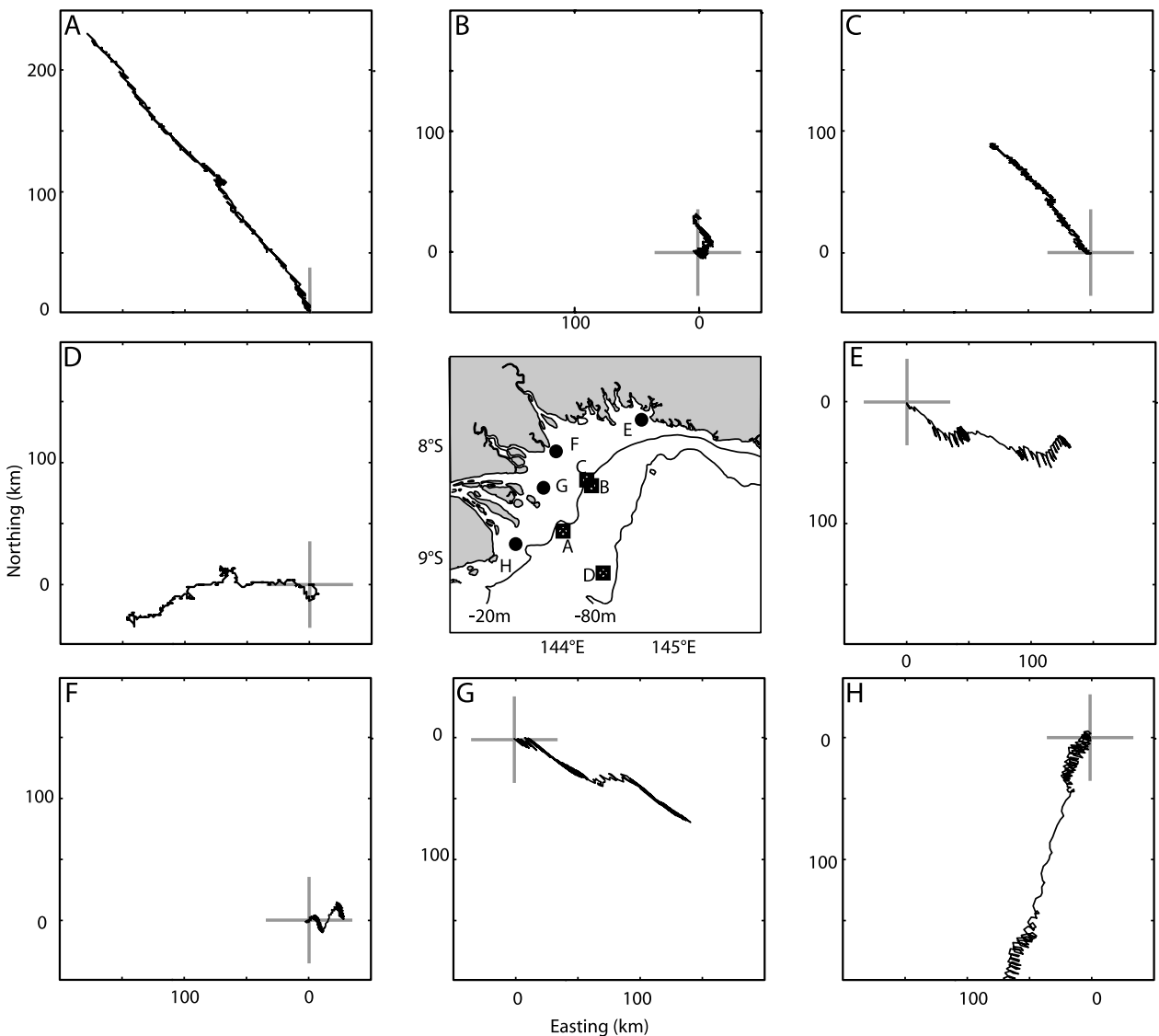

Figure 9. $(\mathrm{a}-\mathrm{d})$ Observed and $(\mathrm{e}-\mathrm{h})$ NCOM-predicted progressive vectors of near-bed currents during trade wind conditions (24 August to 20 September 2003) at various sites on the Holocene clinoform (see inset and Figure 1 for locations): (a) T8-35; (b) T13-30; (c) T13-20; (d) T4-70; (e) NCOM node 161,180; (f) NCOM node 153,155; (g) NCOM node 140,151; and (h) NCOM node 123,126.

combination causes coastal setup and a landward migration of the CSC. The interval 1-27 September is presented here as typical of circulation during the 2003 trade winds (Figure 12).

[40] NCOM-predicted, low-pass-filtered surface flows on the topset during the trade winds (Figure 12a) reveal two flow regimes separated by the Fly River delta. The northern regime is characterized by northeast directed surface currents of approximately $0.02 \mathrm{~m} \mathrm{~s}^{-1}$, and contains a persistent coastal jet originating near the northern distributary of the Fly River. This topset flow is similar in magnitude to those during the monsoon season but it is more isobath parallel. The southern regime consists of currents that flow to the
SW and ultimately enter Torres Strait. The Fly River outflow from the far northern channel traverses the topset in a broad arc to the SE and flows off the topset over a notable promontory in the clinothem (see Figure 1).

[41] Surface currents within the CSC seaward of the shelf edge exceed $1 \mathrm{~m} \mathrm{~s}^{-1}$ during the trade winds and this northeast flow impacts both topset and foreset currents. Predicted surface currents over the foreset follow isobaths and reach $0.1 \mathrm{~m} \mathrm{~s}^{-1}$, and topset flow midway between the Fly River and northern coast is deflected landward.

[42] Observed surface residual flows at tripod deployment sites $\mathrm{T} 13-20$ and $\mathrm{T} 13-30$ on the rollover are roughly

Table 4. Observed Mean Low-Frequency Currents Filtered at 38 h Rotated Into Across- and Along-Isobath Directions ${ }^{\mathrm{a}}$

\begin{tabular}{|c|c|c|c|c|c|}
\hline Location & Season & $\begin{array}{l}\text { Near-Bed } \\
\text { Low Frequency } \\
\text { Flow Along } \\
\text { Isobath, } \mathrm{cm} \mathrm{s}^{-1}\end{array}$ & $\begin{array}{l}\text { Near-Bed } \\
\text { Low-Frequency } \\
\text { Flow Across } \\
\text { Isobath, } \mathrm{cm} \mathrm{s}^{-1}\end{array}$ & $\begin{array}{c}\text { Surface } \\
\text { Low-Frequency } \\
\text { Flow Along } \\
\text { Isobath, } \mathrm{cm} \mathrm{s}^{-1}\end{array}$ & $\begin{array}{c}\text { Surface } \\
\text { Low-Frequency } \\
\text { Flow Across } \\
\text { Isobath, } \mathrm{cm} \mathrm{s}^{-1}\end{array}$ \\
\hline \multirow[t]{3}{*}{ Monsoon } & T13-20 & $-0.2 \mathrm{SW}$ & 7.1 on & $5.8 \mathrm{NE}$ & -5.6 off \\
\hline & T10-20 & $-1.0 \mathrm{SW}$ & 2.5 on & $5.4 \mathrm{NE}$ & 0.7 on \\
\hline & T8-16 & $2.7 \mathrm{NE}$ & 5.4 on & - & - \\
\hline \multirow[t]{3}{*}{ Trade winds } & T13-20 & $1.0 \mathrm{NE}$ & 4.8 on & $-0.3 \mathrm{SW}$ & 1.9 on \\
\hline & T13-30 & $1.0 \mathrm{NE}$ & 0.8 on & $-1.9 \mathrm{SW}$ & 2.2 on \\
\hline & T8-35 & $1.9 \mathrm{NE}$ & 7.9 on & - & - \\
\hline
\end{tabular}

${ }^{\mathrm{a}}$ All data series were approximately $28 \mathrm{~d}$ long with the exception of T8-16, which was $13 \mathrm{~d}$ in duration. On, onshore; off, offshore. 


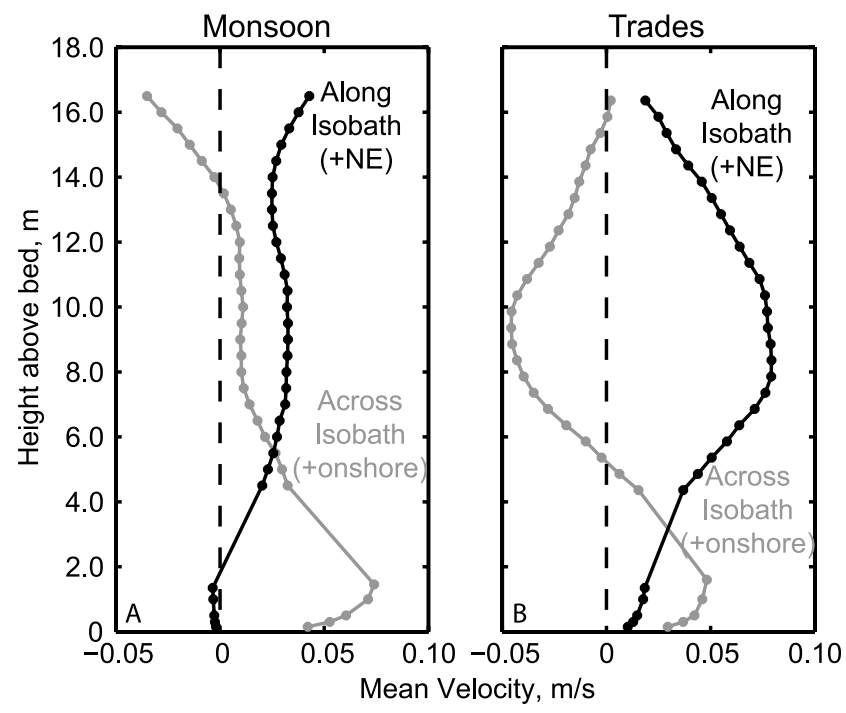

Figure 10. Observed time-averaged flows at site T13-20 for (a) monsoon winds (12 January to 7 February 2004) and (b) trade winds (25 August to 25 September 2004). During the monsoon, currents at this site are obliquely landward to the north for all but the upper few meters, whereas during the trades, currents are generally seaward and to the NE, except in the lower $4 \mathrm{~m}$.

consistent with these predictions. Observed isobath-parallel net surface flow was negligible, alternating in direction between NE and SW (Table 4) coincident with changes in intensity of the NW winds. Observed isobath-perpendicular residual flows alternated between landward and seaward, with weak (0.02 $\left.\mathrm{m} \mathrm{s}^{-1}\right)$ landward flows dominating. The time-averaged vertical profile of currents observed at site T13-20 (Figure 10) shows that oblique NE directed seaward flows in the midwater column exist on top of landward flows near the bed, consistent with NCOM predictions (Figures 12a and 12b). Farther seaward the effect of the CSC is increasingly felt. Predicted surface currents over the foreset are deflected off to the NE along isobaths (Figure 12a) at speeds greater than $0.1 \mathrm{~m} \mathrm{~s}^{-1}$.

[43] The predicted residual near-bottom currents (Figures 12b and $8 \mathrm{e}-8 \mathrm{~h}$ ) over much of the topset have different orientations from the surface flows and their magnitudes are weaker $\left(\sim 0.01\right.$ to $\left.0.03 \mathrm{~m} \mathrm{~s}^{-1}\right)$. The near-bottom flow is landward over most of the outer topset, changing to isobath-parallel flow to the NE, landward of the $8 \mathrm{~m}$ isobath. Note, however, that the flow is highly variable. For example, net bottom drift is seaward only a short distance east of the Kikori River (Figure 9e). This shelf flow is caused by freshwater input from the rivers, which produces stratification over the outer topset and near river mouths. Both the northern and southern coastal jets from the Fly River appear to be barotropic however, because of shallow nearshore depths and vertical mixing. The northern jet has a net seaward motion near the Turama River (Figure 9f) because of interaction with the variable coastline morphology.

[44] The predicted low-pass-filtered flow over the foreset is baroclinic. Near-bed currents follow isobaths to the NE and exceed $0.1 \mathrm{~m} \mathrm{~s}^{-1}$ at the base of the foreset, but decrease to $0.05 \mathrm{~m} \mathrm{~s}^{-1}$ while becoming more northward in shallower water at its top. Near-bed flow near the northern distributary of the Fly River is complex; a mean landward flow within the Umuda Valley (Figure 12b) converges with seaward flow because of river discharge (Figure $9 \mathrm{~g}$ ), creating a weak zone of upwelling on the topset. Near-bed waters near the southern distributary of the Fly flow along shelf to the south-southwest (Figure 9h) and then seaward, bypassing the foreset by following the axis of a bathymetric channel, which may be a submerged river valley.

[45] These predictions are generally consistent with nearbed residual currents observed at tripod deployment site T13-20 (Figures 7 and 10 and Table 4). Observed isobathparallel filtered flows were generally weak during the observation period, peaking at $0.05 \mathrm{~m} \mathrm{~s}^{-1}$ to the NE during the times of peak winds, with weak $\left(0.01 \mathrm{~m} \mathrm{~s}^{-1}\right)$ average flows to the NE. As during the monsoons, weak $\left(0.05 \mathrm{~m} \mathrm{~s}^{-1}\right)$ landward flows are periodically interrupted by short seaward flows during neap tide. Currents on the foreset are directed to the north and northeast along isobaths at speeds of $\sim 0.05$ to $0.1 \mathrm{~m} \mathrm{~s}^{-1}$ over the northern two thirds of the foreset. Interestingly, predicted bottom currents over much of the foreset are stronger than on the topset (Figure 12b).
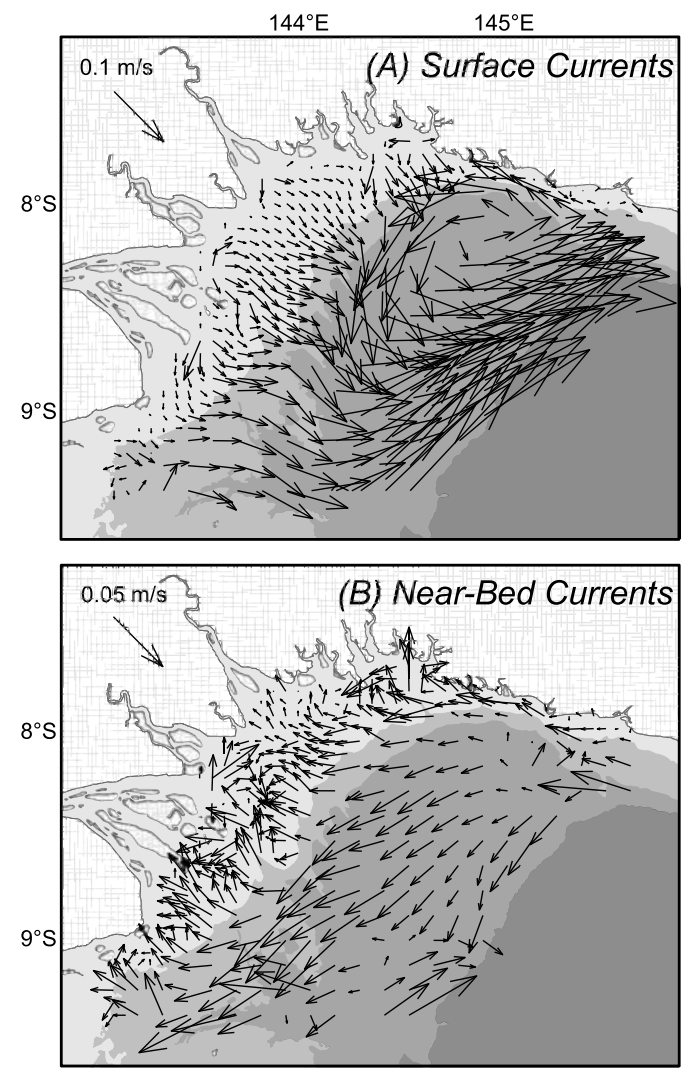

Figure 11. NCOM-predicted, low-pass filtered currents during monsoon conditions (1-27 February 2003). (a) Surface currents, depth-time averaged over $27.5 \mathrm{~d}$ (one lunar cycle); $0.1 \mathrm{~m} \mathrm{~s}^{-1}$ reference vector in top left corner. (b) Near-bed currents (from bottom-most $z$ level), time averaged over $27.5 \mathrm{~d}$ (one lunar cycle); $0.05 \mathrm{~m} \mathrm{~s}^{-1}$ reference vector in top left corner. Bathymetry from light to dark gray in increments of $0-20$ (topset), 20-60 (foreset), 60-160 (outer shelf), and $>160 \mathrm{~m}$. 

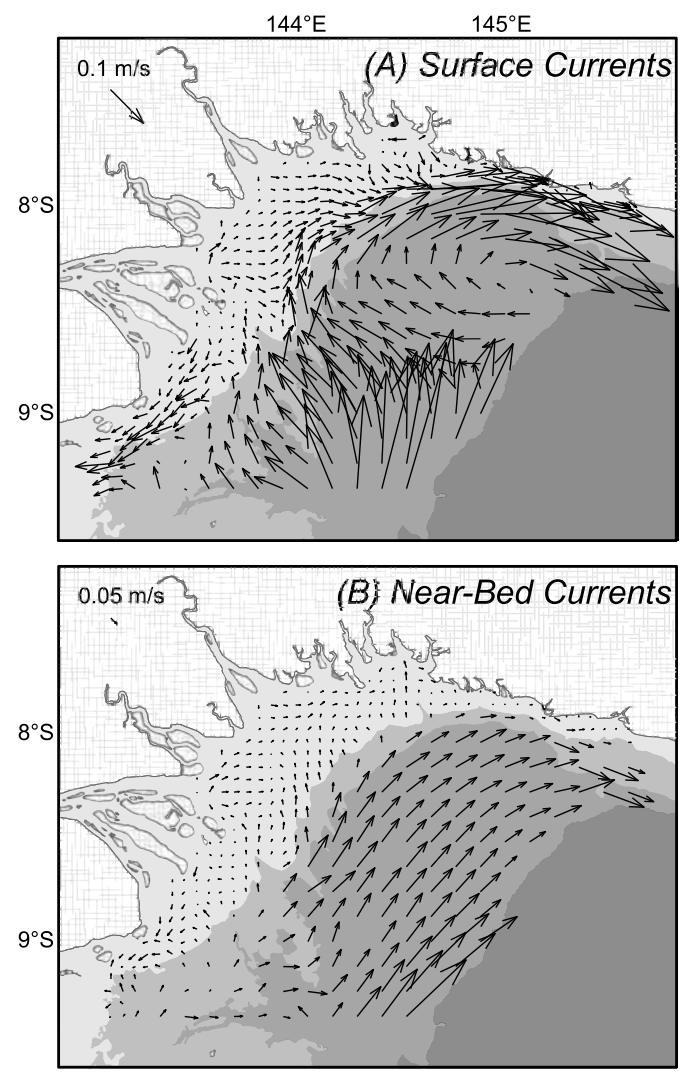

Figure 12. NCOM-predicted, low-pass-filtered currents during trade wind conditions (1-28 September 2003). (a) Surface currents, depth-time averaged over $27.5 \mathrm{~d}$ (one lunar cycle); $0.1 \mathrm{~m} \mathrm{~s}^{-1}$ reference vector in top left corner. (b) Near-bed currents (from bottommost $z$ level), time averaged over $27.5 \mathrm{~d}$ (one lunar cycle); $0.05 \mathrm{~m} \mathrm{~s}^{-1}$ reference vector in top left corner. Bathymetry from light to dark gray in increments of $0-20,20-60,60-160$, and $>160 \mathrm{~m}$.

[46] In summary, tidal flows on the foreset and topset of the Holocene clinothem are strong and directed landward and seaward. Time-averaged residual circulation over the GOP clinoform topset in the monsoon season consists of a seaward directed surface flow and landward near-bed flow reflecting the river plumes and wind-driven coastal upwelling. Seaward, this structure evolves into a SW directed surface current of a 0.1 to $0.3 \mathrm{~m} \mathrm{~s}^{-1}$ over the foreset with accompanying landward directed near-bed currents that sweep obliquely up the foreset to the SW. During the trade wind season the role of river outflows is less clear, as the winds and the CSC play a larger role in the shallow water of the gulf. Both the inner and outer topset are swept by NE directed, isobath-parallel surface currents of up to $0.1 \mathrm{~m} \mathrm{~s}^{-1}$, underneath which are weak, obliquely landward near-bed currents, all containing more saline seaward waters (results not shown).

[47] In summary, low-frequency flows during the trade wind and monsoon seasons of 2003 show large differences in direction, but not in magnitude. Sites such as T13-20 recorded both near-bed and surface flows that on average were stronger during the monsoon season. However, most near-bed and surface flows over the clinothem as hindcast by NCOM were generally a few centimeters per second faster during trade wind conditions.

\subsection{Implications for Sediment Transport}

[48] Even in the absence of wind waves, the results presented above indicate that tidal flows can provide the shear stresses necessary to keep sediment in motion as the wind- and density-driven currents distribute it from the river mouths across and along the shelf. As an estimate of the grain sizes that could be entrained, maximum bed shear stresses were calculated from the maximum near-bed currents experienced over a lunar month at each NCOM computation node (Figure 13). For comparison, the shear stress required to initiate motion for uniform, noncohesive quartz grains ranges from $0.11 \mathrm{~Pa}$ for very fine sand $(0.1 \mathrm{~mm}$ diameter) to $1.1 \mathrm{~Pa}$ for very coarse sand $(1.5 \mathrm{~mm}$ diameter). Thus very fine sand can be mobilized over most of the topset and foreset for a portion of the peak spring tides every month and very coarse sand could be mobilized in most regions of the outer topset, even in the absence of wave shear stresses. These conclusions are similar to results derived by Hemer et al. [2004] using the MECO model, although the directions of residual circulation are quite different. The high shear stresses predicted here for the outer topset during both monsoon and trade wind periods help explain the observed low sedimentation rates sandwiched between slightly higher rates on the inner topset and much higher rates on the foreset [Walsh et al., 2004].

[49] Although point observations and model predictions of currents indicate that sediment should be in motion, observations of turbidity reveal relatively low concentrations. For example, sediment concentrations observed at site T13-17 during peak spring flood currents (Figure 14) were less than $50 \mathrm{mg} \mathrm{L}^{-1}$ in the upper $10 \mathrm{~m}$ of the water column and only reached $\sim 500 \mathrm{mg} \mathrm{L}^{-1}$ in the lowest meter [Martin et al., 2008]. This and other observations of water turbidity in the study area [Harris, 1999; Walsh and Nittrouer, 2003] reveal low values in the surface layer over much of the topset. These low values indicate that although the rivers feeding the study area are thought to deliver about $\sim 365 \mathrm{Mt}$ $\mathrm{a}^{-1}$ to their floodplains and deltas, the process(es) that supply the prograding clinothem must be episodic with temporary storage in the estuaries and/or shallow regions of the topset [Ogston et al., 2008]. The net landward, nearbed, low-frequency flows during 2003 further emphasize this point.

\section{Discussion}

\subsection{Patterns of Coastal Circulation in the Gulf of Papua}

[50] The Gulf of Papua is a complex region of tidal and low-frequency circulation. Baroclinic and wind-driven currents combine with variable morphology to produce a spatially heterogeneous system. Nevertheless, the observations and model results presented above provide two insights into the formation of the clinothem and the patterns of accumulation and mineralogy reported in other papers [Walsh et al., 2004; Slingerland et al., 2008]. The first is that flows in the region shift directions on timescales of hours, weeks, and seasons. Gyres on the topset created by shifts in the predominant wind pattern (e.g., monsoon wind breakouts) cause the along-isobath component of flow to switch direction from NE to SW. Sediment on the topset initially entering from both the northeastern and Fly rivers 

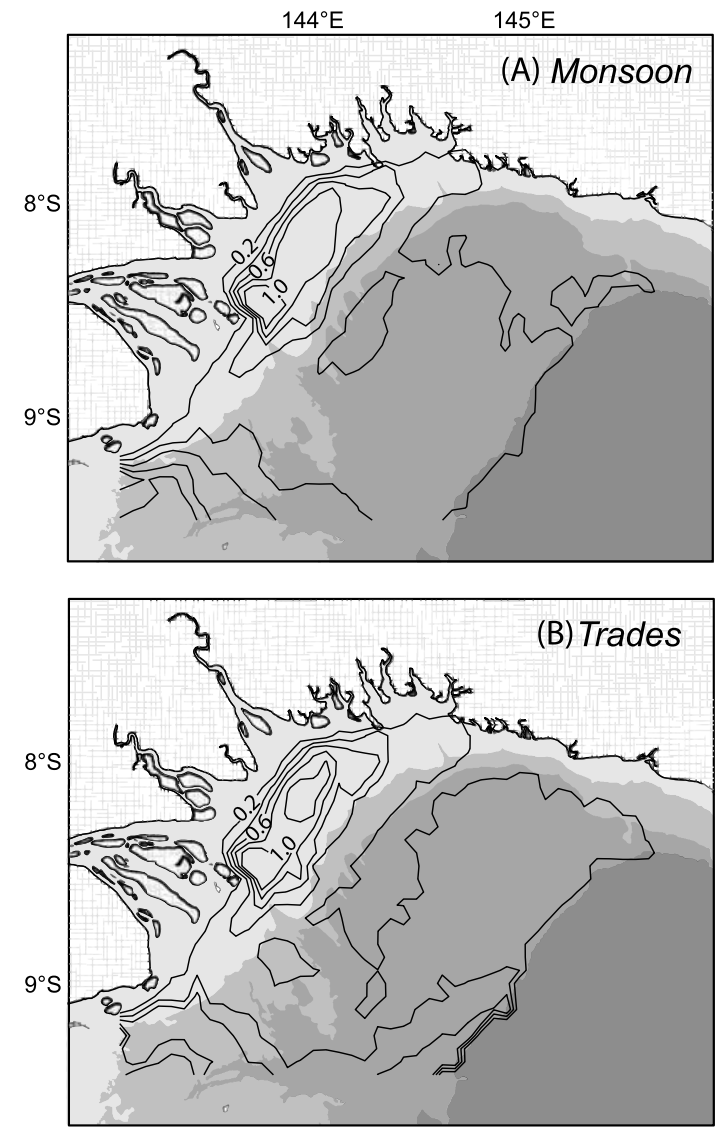

Figure 13. Maximum bed layer shear stress due to currents $(\mathrm{Pa})$ predicted by NCOM over a lunar cycle during (a) monsoon and (b) trade wind seasons. Contour interval is $0.2 \mathrm{~Pa}$. Shear stresses computed as $\rho f U^{2}$ where $\rho=1025 \mathrm{~kg}$ $\mathrm{m}^{-3}$, Darcy-Weisbach friction factor, $f=0.0025$, and $U$ is the largest current magnitude at a site over a lunar cycle. Bathymetry from light to dark gray in increments of -20 , $20-60,60-160$, and $>160 \mathrm{~m}$. Note that maximum bed shear stresses are dictated mainly by tides and therefore show little variation between the two seasons.

has the potential to be spread throughout the broad, shallow central gulf. This helps explain the mineralogical observations of sediment from the northeastern rivers reaching SW almost to the Fly River, and the Fly River-derived sediment extending to the northeast.

[51] The second insight is that gyres create zones of convergence and divergence of flow, as for example in Figure 11a along the foreset and Figure $12 \mathrm{~b}$ in the middle of the topset. These zones localize sedimentation because the water column experiences convergence, settling forces dominate, and areas form with enhanced nearbed suspended-sediment concentrations and seabed accumulation rates.

\subsection{Relationship Between Modeled Circulation and Building the Holocene Clinothem}

[52] Can the coastal currents presented here explain the origin of the Holocene clinothem in the Gulf of Papua, or are high-magnitude events or other processes also necessary? If the observations presented above are strictly inter- preted, then the observed and predicted flows cannot explain the formation and growth of the modern clinothem. Near-bed flows are landward over the outer half of the clinoform, regardless of season. Progressive vector diagrams, maximum bed shear stresses due to tides, and residual flows all show that if sediment flux mirrors nearbed flows, sediment should be transported landward at the bed level over most of the GOP clinoform seaward of the $10 \mathrm{~m}$ isobath. If only near-bed flows carry appreciable sediment, then coastal flows of the sort observed and modeled here provide no mechanism for self-similar clinoform growth.

[53] We can think of a number of means by which to resolve the paradox. First, freshwater and shallow marine processes (e.g., those that occur in the long tidally influenced rivers and the estuaries within the subaerial delta) are not captured with a study of coastal circulation, yet they impact how sediment is fed into the coastal environment. For example, the change from a water column with relatively uniform sediment concentrations to one with sediment concentrated in the boundary layer occurs within the delta [Ogston et al., 2008; Wolanski and Alongi, 1995; Wolanski et al., 1995a, 1995b]. On the very inner topset $(<10 \mathrm{~m} \mathrm{depth})$, there is a zone of temporary storage and fluid muds have been observed [Ogston et al., 2008; Wolanski and Alongi, 1995; Wolanski et al., 1995a, 1995b]. These processes are not included in this study.

[54] Secondly, it is also possible that high-magnitude but low-frequency events not observed during our study are responsible for building the clinothem. For example, river floods could produce a seaward directed turbid plume that temporarily reverses the landward directed near-bed flows underneath it. If flooding happened during the monsoons (and assuming the shelf flow patterns away from the plume were similar to those modeled here), then sediment could be

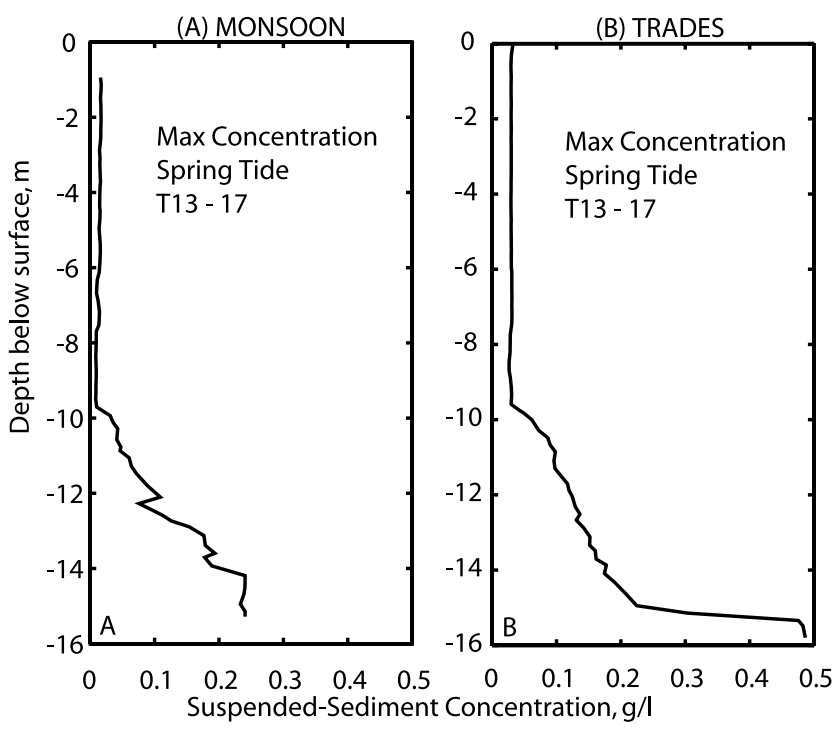

Figure 14. Suspended-sediment concentration $\left(\mathrm{g} \mathrm{l}^{-1}\right)$ observed at profiling site T13-17 during (a) monsoon (6-7 February 2004) and (b) trade wind (9-10 September 2003) conditions. Note that in both cases, suspendedsediment concentration is largest in the bottom $4 \mathrm{~m}$ of the water column. 
carried seaward and deposited on the foreset as the sediment-laden waters are advected to the southwest (cf. Figure 11). To explore this possibility we conducted a simulation during monsoon conditions in which the fluvial discharges were doubled. Results show that near-bed flows are reversed in regions seaward of all river mouths, suggesting that many aspects of the clinothem could be explained by this process. The enhanced flows of the Kikori and Purari Rivers could feed their feldspar-rich sediment to the counterclockwise gyre (Figure 11) that would advect it south along the foreset, thereby explaining the mineralogical observations of Slingerland et al. [2008]. Floods occurring during the trade wind season less easily explain clinothem characteristics; particles in the near-bed layer near river mouths are still not able to escape the topset. However, if only the Fly were to flood during this time, the predicted sediment transport may explain the extension of illite-rich sediment to the NE observed by Slingerland et al. [2008].

[55] During flood conditions, sediment concentrations at the river mouths could become large enough to form nearbed fluid mud or hyperpycnal flows. Both processes could reverse the prevailing landward bottom flows on the shelf. Sediment carried to the clinoform rollover could then accumulate there or flow downslope until the density-driven forces were balanced by drag from the prevailing upslope currents or the density flow collapsed, allowing the sediment to accumulate on the foreset. We do not think highmagnitude coastal flows due to cyclones are a likely cause of clinoform-building, because few documented typhoons have passed over the GOP [Lourensz, 1981].

[56] Thirdly, it may be that we accurately captured the general clinothem-building circulation of the gulf, but did not include in our model a critical additional process such as wave- and current-supported gravity flows or weak depositional sheet turbidity currents. Gravity flows were postulated to exist by Harris et al. [1993], and supporting evidence has been found in the seabed by Walsh et al. [2004] on the basis of 5- to $10-\mathrm{cm}$ clay-rich event beds with low ${ }^{210} \mathrm{~Pb}$ activity. Gravity-driven fluid mudflows were observed in the tripod and water column profiling data, but only during the peak spring tides of the trade wind season [Martin et al., 2008]. As with the circulation patterns shown here, they were temporally episodic and spatially heterogeneous along the clinothem topset.

\section{Conclusions}

[57] In this paper we have investigated the role that tidal and wind-driven flows, sediment-laden plumes, and bottom boundary layers play in the development of the Holocene clinothem in the Gulf of Papua. Field observations and computer model predictions during 2003 and 2004 allow us to draw the following conclusions.

[58] 1. Tidal flows on the topset and foreset are strong and alternately landward and seaward in direction. Peak spring tidal velocities can provide the shear stresses necessary to keep sediment in motion as the wind-driven and haline currents distribute it from the river mouths across and along the shelf. Stresses are strong enough that sediment up to very fine sand size could be mobilized over most of the topset and foreset for a portion of every month and very coarse sand could be mobilized in most regions of the topset, even in the absence of wave shear stresses.

[59] 2. Circulation of waters in the monsoon season over the GOP clinoform topset consists of a seaward surface flow and landward bottom flow, reflecting the river plumes and wind-driven coastal upwelling. Seaward, this structure evolves into a SW directed surface current over the foreset with accompanying weak, landward directed, near-bed currents that sweep obliquely up the foreset to the WSW. During the trade wind season the role of river outflows is less clear as the winds and Coral Sea Current play a larger role in the shallow water of the gulf. Both the inner and outer topset are swept by NE directed, contour-parallel surface currents, beneath which are weak, obliquely landward near-bed currents, all made up of more saline offshore waters.

[60] 3. The coastal circulation patterns vary both temporally (on hourly to seasonal scales) and spatially over the active clinothem. Gyres on the topset form with shifts in wind patterns throughout the monsoon and trade wind periods. Many aspects of the clinothem can be explained by these flows, such as mixing of sediment supplied by diverse rivers entering the GOP and the spatial convergence of suspended sediment in the central GOP. However, if only near-bed flows carry appreciable sediment on the clinoform top, as available observations document, then coastal flows of the sort observed and modeled here provide no mechanism for self-similar clinothem growth. High-magnitude but low-frequency events also seem to be necessary, such as periods of very high concentrations of suspended sediment in the bottom boundary layer and associated gravity flows. These have been observed to occur on the topset, but are spatially heterogeneous. The shallow water convergence zones in the circulation could help explain those occurrences.

[61] Acknowledgments. This research was supported by National Science Foundation awards OCE-0203351, -0305699, -0305779, and -0305607 under the MARGINS S2S Initiative. Thanks to Scott Miller for help on the graphics and Peter Harris of Geoscience Australia for the contribution of current meter data at site T8-35. We thank our reviewers, Jerry Dickens, Frederic Saint-Cast, and Charles Nittrouer and an anonymous reviewer, for helpful comments.

\section{References}

Andrews, J. C., and S. Clegg (1989), Coral sea circulation and transport deduced from modal information models, Deep Sea Res., Part A, 36, 957-974.

Asselin, R. (1972), Frequency filter for time integrations, Mon. Weather Rev., $100(6), 487-490$.

Barron, C. N., L. F. Smedstad, R. C. Rhodes, A. B. Kara, C. Rowley, R. A Allard, and H. E. Hurlburt (2004), Validation of the $1 / 8^{\circ}$ global Navy Coastal Ocean Model nowcast/forecast system, in NAVO MSRC Navigator, Spring, pp. 5-8, Major Shared Resour Cent., Nav. Oceanogr. Off., Stennis Space Cent., Miss.

Bayler, G., and H. Lewit (1992), The Navy operational global and regional atmospheric prediction systems at the fleet numerical oceanography center, Weather Forecasting, 7(2), 273-279.

Bostock, H. C., B. N. Opdyke, M. K. Gagan, A. E. Kiss, and L. K. Fifield (2006), Glacial/interglacial changes in the East Australian Current, Clim. Dyn., 26(6), 645-659.

Brunskill, G. J. (2004), New Guinea and its coastal seas, a testable model of wet tropical coastal processes: An introduction to project TROPICS, Cont. Shelf Res., 24, 2273-2295.

Cattaneo, A., A. Correggiari, L. Langone, and F. Trincardi (2003), The lateHolocene Gargano subaqueous delta, Adriatic shelf: Sediment pathways and supply fluctuations, Mar. Geol., 193, 61-91.

Cattaneo, A., F. Trincardi, L. Langone, A. Asioli, and P. Puig (2004), Clinoform generation on Mediterranean margins, Oceanography, 17(4), $105-117$. 
Chen, Z., Y. Saito, K. Hori, Y. Zhao, and A. Kitamura (2003), Early Holocene mud-ridge formation in the Yangtze offshore, China: A tidal-controlled estuarine pattern and sea-level implications, Mar. Geol., 198, 245-257.

Crockett, J. S., C. A. Nittrouer, A. S. Ogston, and M. A. Goni (2008), Variable styles of sediment accumulation impacting strata formation on a clinoform: Gulf of Papua, Papua New Guinea, in The Fly River. Natural and Human Aspects of a Complex Fluvial System, Dev. Earth Environ. Sci., vol. 9, edited by B. R. Bolton, Elsevier, New York, in press.

Dalrymple, R. W., E. K. Baker, P. T. Harris, and M. G. Hughes (2003), Sedimentology and stratigraphy of a tide-dominated, foreland-basin delta (Fly River, Papua New Guinea), Spec. Publ. Soc. Sediment. Geol., 76, $147-173$.

Driscoll, N. W., and G. D. Karner (1999), Three-dimensional quantitative modeling of clinoform development, Mar. Geol., 154, 383-398.

Egbert, G. D., and S. Y. Erofeeva (2002), Efficient inverse modeling of barotropic ocean tides, J. Atmos. Oceanic Technol., 19(2), 183-204.

Friedrichs, C. T., and L. D. Wright (1994), The critical role of the alongshelf current in determining dominant modes of sediment transport across the shoreface (inner shelf), Eos Trans. AGU, 75(44), Fall Meet. Suppl., Abstract O22A-16.

Gentilli, J. (1971), Dynamics of the Australian troposphere, in World Survey of Climatology: Climates of Australia and New Zealand, edited by J. Gentilli, pp. 53-117, Elsevier, New York.

Harris, P. T. (1990), Sedimentation at the junction of the Fly River and the northern Great Barrier Reef, in Sustainable Development for Traditional Habitats of the Torres Strait Region, Workshop Ser, vol. 16, edited by D. Lawrence and T. Cansfield-Smith, pp. 59-85, Great Barrier Reef Mar. Park Auth., Townsville, Queensland, Australia.

Harris, P. T. (1999), Environmental management of Torres Strait: A marine geologist's perspective, in Gondwana to Greenhouse: Environmental Geoscience-An Australian Perspective, edited by V. A. Gostin, pp. 317-328, Geol. Soc. of Austr., Sydney, N. S. W., Australia.

Harris, P. T., E. K. Baker, A. R. Cole, and S. A. Short (1993), A preliminary study of sedimentation in the tidally dominated Fly River delta, Gulf of Papua, Cont. Shelf Res., 13, 441-472.

Harris, P. T., C. B. Pattiaratchi, J. B. Keene, R. W. Dalrymple, J. W. Gardner, E. K. Baker, A. R. Cole, D. M. Mitchell, P. Gibbs, and W. W. Schroeder (1996), Late Quaternary deltaic and carbonate sedimentation in the Gulf of Papua foreland basin: Response to sea-level change, J. Sediment. Res., 66(4), 801-819.

Harris, P. T., A. Heap, V. Passlow, M. Hughes, J. Daniell, and O. B. Anderson (2003), Evidence for low sea level incision of the Gulf of Papua Shelf by the Fly River and by tidal currents during the Quaternary, Eos Trans. $A G U, 84(46)$, Fall Meet. Suppl., Abstract OS11A-03.

Harris, P. T., M. G. Hughes, E. K. Baker, R. W. Dalrymple, and J. B. Keene (2004), Sediment transport in distributary channels and its export to the pro-deltaic environment in a tidally dominated delta: Fly River, Papua New Guinea, Cont. Shelf Res., 24, 2431-2454.

Hemer, M. A., P. T. Harris, R. Coleman, and J. Hunter (2004), Sediment mobility due to currents and waves in the Torres Strait-Gulf of Papua region, Cont. Shelf Res., 24, 2297-2316.

Hori, K., Y. Saito, Q. Zhao, and P. Wang (2002), Architecture and evolution of the tide-dominated Changjiang (Yangtze) River delta, China, Sediment. Geol., 146(3-4), 249-264.

Johnstone, E. A., N. W. Driscoll, R. L. Slingerland, J. D. Milliman, and J. Babcock (2006), Clinoform architecture in the Gulf of Papua records the interplay between sea level, sediment supply, and climate, Eos Trans., $A G U, 87(36)$, Abstract OS16A-36.

Keen, T. R., D. S. Ko, R. L. Slingerland, S. Riedlinger, and P. Flynn (2006), Potential transport pathways of terrigenous material in the Gulf of Papua, Geophys. Res. Lett., 33, L04608, doi:10.1029/2005GL025416.

Kineke, G. C., R. W. Sternberg, J. H. Trowbridge, and W. R. Geyer (1996), Fluid-mud processes on the Amazon continental shelf, Cont. Shelf Res., $16,667-696$.

Kostic, S., and G. Parker (2003a), Progradational sand-mud deltas in lakes and reservoirs: Part 2, Experimental and numerical simulation, J. Hydraul. Res., 41(2), 141-152.

Kostic, S., and G. Parker (2003b), Progradational sand-mud deltas in lakes and reservoirs: Part 1, Theory and numerical modeling, J. Hydraul. Res., 41(2), 127-140

Kuehl, S. A., C. A. Nittrouer, and D. J. DeMaster (1982), Modern sediment accumulation and strata formation on the Amazon continental shelf, Mar. Geol., 49, 279-300.

Liu, J. P., J. D. Milliman, S. Gao, and P. Cheng (2004), Holocene development of the Yellow River's subaqueous delta, North Yellow Sea, Mar. Geol., 209, 45-67.

Liu, J. P., K. H. Xu, A. C. Li, J. D. Milliman, D. M. Velozzi, S. B. Xiao, and Z. S. Yang (2005), Flux and fate of the Yangtze River sediments delivered to the East China Sea, Geomorphology, 85(3-4), $208-224$.

Lourensz, R. S. (1981), Tropical Cyclones in the Australian Region, July 1909 to June 1980, Austr. Gov. Publ. Serv., Parkes, ACT, Australia.

Martin, D. P., C. A. Nittrouer, A. S. Ogston, and J. S. Crockett (2008), Tidal and seasonal dynamics of a muddy inner shelf environment, Gulf of Papua, J. Geophys. Res., 113, F01S07, doi:10.1029/2006JF000681.

Martin, P. J. (2000), Description of the Navy Coastal Ocean Model version 1.0, 45 pp., Nav. Res. Lab., Stennis Space Cent., Miss.

Mellor, G. L. (1991), An equation of state for numerical-models of oceans and estuaries, J. Atmos. Oceanic Technol., 8(4), 609-611.

Mellor, G. L., and T. Yamada (1982), Development of a turbulence closure model for geophysical fluid problems, Rev. Geophys., 20, $851-875$.

Milliman, J. D. (1995), Sediment discharge to the ocean from small mountainous rivers: The New Guinea example, Geo Mar. Lett., 15(3-4), 127133

Milliman, J. D., N. W. Driscoll, R. L. Slingerland, J. Babcock, and J. P. Walsh (2004), Isotopic stage 3 deposition and stage 2 erosion of a clinoform in the Gulf of Papua: Regional tectonics versus eustatic sea-level change, Eos Trans. AGU, 85(47), Fall Meet. Suppl., Abstract OS44A-05.

Milliman, J. D., K. H. Xu, G. J. Brunskill, R. L. Slingerland, and N. W. Driscoll (2006), Sediment mineralogy on the Gulf of Papua clinoform: New insights into sediment sources and redistribution processes, Eos Trans. $A G U, 87(36)$, Ocean Sci. Meet. Suppl., Abstract OS16A-25.

Mitchum, R. M., P. R. Vail, and J. B. Sangree (1977), Seismic stratigraphy and global changes of sea level: Part 6, Stratigraphic interpretation of seismic reflection patterns in depositional sequences, in Seismic Stratigraphy: Applications to Hydrocarbon Exploration, edited by C. E. Payton, pp. 135-143, Am. Assoc. of Pet. Geol., Tulsa, Okla.

Muhammad, Z., S. J. Bently, A. W. Droxler, G. R. Dickens, B. N. Opdyke, and L. C. Peterson (2004), Sediment flux to the Gulf of Papua continental slope using $\mathrm{Pb}-210$ geochronology, sources to sink Papua New Guinea focus area, Eos Trans. $A G U, 85(47)$, Fall Meet. Suppl., Abstract OS51B1301.

Nittrouer, C. A., S. A. Kuehl, D. J. DeMaster, and R. O. Kowsmann (1986), The deltaic nature of Amazon shelf sedimentation, Geol. Soc. Am. Bull., 97(4), 444-458.

Nittrouer, C. A., S. A. Kuehl, A. G. Figueiredo, M. A. Allison, C. K. Sommerfield, J. M. Rine, L. E. C. Faria, and O. M. Silveira (1996) The geological record preserved by Amazon shelf sedimentation, Cont. Shelf Res., 16, 817-841.

Ogston, A. S., R. W. Sternberg, C. A. Nittrouer, D. P. Martin, M. A. Goñi, and J. S. Crockett (2008), Sediment delivery from the Fly River tidally dominated delta to the nearshore marine environment and the impact of El Niño, J. Geophys. Res., 113, F01S11, doi:10.1029/2006JF000669.

Parker, G. (2006), Theory for a clinoform of permanent form on a continental margin emplaced by weak, dilute muddy turbidity currents, in Proceedings of the 4th IAHR Symposium on River, Coastal and Estuarine Morphodynamics, RCEM 2005, 4-7 October 2005, edited by G. Parker and M. H. Garcia, pp. 553-561, Taylor and Frances, Philadelphia, Pa.

Pickup, G. (1984), Geomorphology of tropical rivers: I. Landforms, hydrology and sedimentation in the Fly and Lower Purari, Papua New Guinea, Catena Suppl., 5, 1-17.

Pratson, L. F., et al. (2004), Modeling continental shelf formation in the Adriatic Sea and elsewhere, Oceanography, 17(4), 119-131.

Ridgway, K. R., J. S. Godfrey, G. Meyers, and R. Bailey (1993), Sea level response to the 1986-1987 El Niño-Southern event in the western Pacific in the vicinity of Papua New Guinea, J. Geophys. Res., 98(C9), $16,387-16,396$

Salomons, W., and A. M. Eagle (1990), Hydrology, sedimentology and the fate and distribution of copper in mine-related discharges in the fly river system, Papua New Guinea, Sci. Total Environ., 97-98, 315334

Selover, R. W., R. Slingerland, T. R. Keen, N. W. Driscoll, and J. D. Milliman (2006), Ocean circulation and sediment transport paths in the Gulf of Papua, Eos Trans. $A G U, 87(36)$, Ocean Sci. Meet. Suppl., Abstract OS13J-03.

Slingerland, R. L., J. D. Milliman, N. W. Driscoll, J. P. Walsh, and T. R. Keen (2004), Development of the Holocene clinoform in the Gulf of Papua, Eos Trans. AGU, 85(47), Fall Meet. Suppl., OS44A-06.

Slingerland, R., N. W. Driscoll, J. D. Milliman, S. R. Miller, and E. A. Johnstone (2008), Anatomy and growth of a Holocene clinothem in the Gulf of Papua, J. Geophys. Res., 113, F01S13, doi:10.1029/ 2006JF000628.

Smagorinsky, J. (1963), General circulation experiments with the primitive equations, Mon. Weather Rev., 91(3), 99-164.

Traykovski, P. A., W. R. Geyer, J. D. Irish, and J. F. Lynch (2000), The role of wave-induced density-driven fluid mud flows for cross-shelf transport on the Eel River continental shelf, Cont. Shelf Res., 20, 2113-2140. 
Walsh, J. P., and C. A. Nittrouer (2003), Contrasting styles of off-shelf sediment accumulation in New Guinea, Mar. Geol., 196, 105-125.

Walsh, J. P., C. A. Nittrouer, C. M. Palinkas, A. S. Ogston, R. W. Sternberg, and G. J. Brunskill (2004), Clinoform mechanics in the Gulf of Papua, New Guinea, Cont. Shelf Res., 24, 2487-2510.

Wolanski, E. (1994), Physical Oceanographic Processes of the Great Barrier Reef, 194 pp., CRC Press, Boca Raton, Fla.

Wolanski, E., and D. M. Alongi (1995), A hypothesis for the formation of a mud bank in the Gulf of Papua, Geo Mar. Lett., 15(3-4), 166 171.

Wolanski, E., and M. Eagle (1991), Oceanography and fine sediment transport, Fly River estuary and Gulf of Papua, Publ. 21, pp. 453-457, Wate Qual. Cent., Natl. Agric. Libr., Beltsville, Md.

Wolanski, E., and B. King (1990), Flushing of Bowden Reef Lagoon, Great Barrier Reef, Estuarine Coastal Shelf Sci., 31, 789-804.

Wolanski, E., G. L. Pickard, and D. L. B. Jupp (1984), River plumes, coral reefs and mixing in the Gulf of Papua and the northern Great Barrier Reef, Estuarine Coastal Shelf Sci., 18, 291-314.
Wolanski, E., B. King, and D. Galloway (1995a), Dynamics of the turbidity maximum in the Fly River estuary, Papua New Guinea, Estuarine Coastal Shelf Sci., 40, 321-337.

Wolanski, E., A. Norro, and B. King (1995b), Water circulation in the Gulf of Papua, Cont. Shelf Res., 15, 185-212.

N. W. Driscoll, Scripps Institution of Oceanography, GRD 0244, La Jolla, CA 92093, USA.

T. R. Keen, Naval Research Laboratory, 1009 Balch Boulevard, Stennis Space Center, MS 39529, USA.

J. D. Milliman, School of Marine Science, College of William and Mary, 1208 Greate Road, Gloucester Point, VA 23062, USA.

A. S. Ogston, School of Oceanography, University of Washington, Box 357940, Seattle, WA 98195, USA.

R. W. Selover and R. Slingerland, Department of Geosciences, Pennsylvania State University, 513A Deike, University Park, PA 16802 USA. (sling@geosc.psu.edu) 